\title{
FIELD STUDIES ON THE SURFACE FAUNA OF FORESTS
}

\author{
by \\ J. VAN DER DRIFT \\ Institute for Biological Field Rersearch (ITBON), Arnhem
}

\section{CONTENTS}

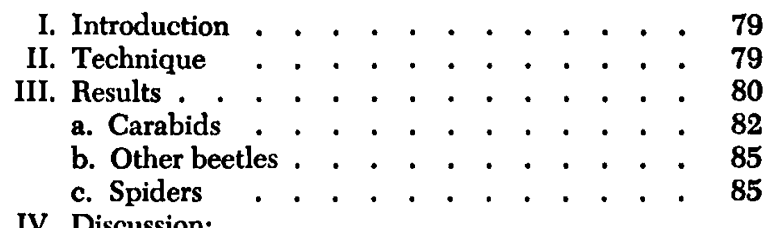

IV. Discussion:

a. Comparison with other results . . . . . 86 b. The lifecycle of Carabus problematicus Herbst . . . . . . . . . . . . . 87

c. Fluctuations in population density . . . 90

d. Local distribution . . . . . . . . . 94

e. Phenology . . . . . . . . . . . 100

V. Conclusion and Summary . . . . . . . . 102

VI. Literature . . . . . . . . . . . . . 103

\section{INTRODUCTION}

In most handbooks on forest entomology much stress is laid on the importance of predatory arthropods in the soil as enemies for pupating noxious insects (Escheruch, 1923; Graham, 1939). However, detailed investigations in the field on the significance of these predators are scarce.

In Germany much work has been done on the biology and feeding habits of Carabus species (KERN, 1921; Lengerken, 1921; Oertel, 1924; DelkesKAMP, 1930; KIRChENER, 1927; JUNG, 1940) but these observations and experiments were mainly done under laboratory conditions. Forbes $(1880,1882)$ investigated the gut contents of many carabid species and concluded that about $1 / 3-1 / 4$ of the food was of animal origin. VIrE (1953) studied the significance of spiders in forests.

If a predator is of importance as an enemy of noxious insects its activity must coincide with the activity of these insects. In the case of soil-surface predators these predators must be active at the time that noxious insects are present at the soil surface, e.g., caterpillars creeping around in search of pupation sites.

For a better evaluation of the significance of the soil-surface predators more knowledge of the feeding habits and the period of activity in the field is desirable. This study is only concerned with the second question. It is hoped that a field study of the feeding habits can be published later.

Little is known concerning the period of activity of predators. LARSSON (1939) in Denmark and LindRотн in Sweden are the only investigators, who worked on carabids in this field. Recently GilberT (1956) published a study on the life history of four species of Calathus. The results of LARsson and LINDROTH are mainly based on capture frequencies of adult specimens in museum material and on the occurrence of larvae. Often information from these data was of necessity somewhat vague and sometimes even unreliable.

This study is intended to elucidate the activity periods of the surface fauna by means of a direct method and to connect these activity periods with the life cycles of the species. For this purpose a trap technique was used. Traps were put in different forest areas and trapping was continued during several years.

Besides information on the activity period and lifecycle, which is the main object of this paper, the data yielded information about fluctuations in population density, local distribution and phenology. These results are reviewed in the "Discussion".

\section{TECHNIQUE}

The trap technique used in this study was described in a previous paper (vaN DER DRIFT, 1951, p. 35). Biscuit-tins with a surface of $24 \mathrm{~cm}$ square and a depth of $25 \mathrm{~cm}$, were sunk to the rim into the ground.
A draining hole in the bottom was covered with a small-mesh wire-netting. Animals, actively running on the soil surface, fell into the trap and were collected weekly. Some succeeded in escaping during 
the week by flying out (very seldom) or by climbing out along the sides of the tin. It is evident that the method is not equally efficient for the different species. However, for any one species the numbers trapped during a certain time are sufficiently comparable with respect to season and place to indicate seasonal activity and local density.

The captures were made in two adjacent oakwoods near Hoenderloo (Veluwe) and in a Scots pine wood at Schaarsbergen near Arnhem, both situated on dry and poor sandy soils. In the two oakwoods 10 traps were put in two rows of 5 , rows and traps in each of the rows being 10-20 metres apart. Trapping was done from March 1950 till November 1952. In the Scots pine wood 20 traps were put in 4 rows of 5 , rows and traps in each of the rows 50 metres apart. Here trapping started in March 1951 and was continued until November 1955.

The first oakwood (oak-mull) occupies $1 / 2$ ha. The oaks are about 50 years old, 15 metres high with diameters averaging $18.5 \mathrm{~cm}$ (breast height). The canopy covers about $90 \%$ of the ground. The undergrowth consists of a patchy vegetation of Holcus mollis L., Poa pratensis L., Stellaria media Cyrillo, Urtica dioica L., Rubus sp., Aegopodium podagraria L., Glechoma hederacea L., Vinca minor L., and Ampelopsis quinquefolia R. et Sch. The litter occupies about $30 \%$ of the area and forms only a thin layer. The soil may be characterised as a mull; it has a loose and crumbly structure and is rich in humus. This favourable condition and the rich herbaceous vegetation may be the result of the regular deposition of refuse from an adjacent garden. From this plot the surface slopes slightly $(2-3 \%)$ to the second plot. Height of the trees and soil conditions diminish regularly down the slope and the rich herbaceous undergrowth is replaced by a vegetation composed of Vaccinium, grass and mosses. This second plot (oak-mor) is situated at a distance of about 150 metres from the first one. The oaks are of the same age but they are only 13.5 metres high with diameters averaging $14.5 \mathrm{~cm}$. The canopy covers $85 \%$ of the ground. The undergrowth consists of Vaccinium Myrtillus L., Deschampsia flexuosa Trin. and Polytrichum commune L., leaving only small patches of litter. The soil is a true mor: an $8 \mathrm{~cm}$ thick layer of litter and raw humus covers the mineral soil, which is poor in organic material.

The plot in the Scots pine wood occupies about 5 ha (approx. 12 acres) and is surrounded by other stands of Scots pine. All the trees are of the same age (approx. 50 years), but in the northern part, the stand of the trees is rather close, the height varies from 8-10 metres and the undergrowth consists mainly of the moss Pleurozium schreberi Mitten, which occupies about $70 \%$ of the surface, the balance being pine needle litter. The layer of moss, litter and humus is $5-8 \mathrm{~cm}$ thick. In the southern part the stand is very open, the trees are only 5-7 metres high and the undergrowth consists of a patchy vegetation of heather, Calluna vulgaris Hull, especially on the open spots, Cladonia sp., Hypnum cupressiforme $\mathrm{L}$. and several other mosses. Here the layer of moss, needles and humus is about $3 \mathrm{~cm}$ thick. The difference between the two areas is caused partly by the soil texture since a layer of very coarse sand comes near the surface in the southern part, and partly by cultural circumstances since the northern part, which previously carried oak coppice was subsequently tilled before the planting of the oak stand. In November 1954 all trees in the southern part were felled and in June 1955 the plot was ploughed.

\section{RESULTS}

Since it is not practicable to present the complete data for all species here, they were deposited in the library of the Institute. Only one species, Pterostichus oblongopunctatus $\mathrm{F}$., will be treated in full. This is a medium sized carabid which was abundant in all three areas during the period of study. The results are summarised in the histogram in Fig. 1. In the histogram the columns directed upwards represent the number of males and those directed downwards the number of females caught weekly. The reproductive period extends from spring until mid-summer, newly emerged imagines are present in autumn.
It is evident that the histograms of the populations in the different woods and from the different years agree closely. Some difference may be seen in the first occurrence of the young imagines in the pineand oakwoods. Also the point at which activity begins in spring may vary some weeks in the different years. These phenomena will be discussed in the section on phenology. They are, however, of minor importance with respect to the general appearance of the histogram. The same applies to the other species.

Before considering the results it is important to stress the fact that the increase and the decrease in the number of captures throughout the year are caused 


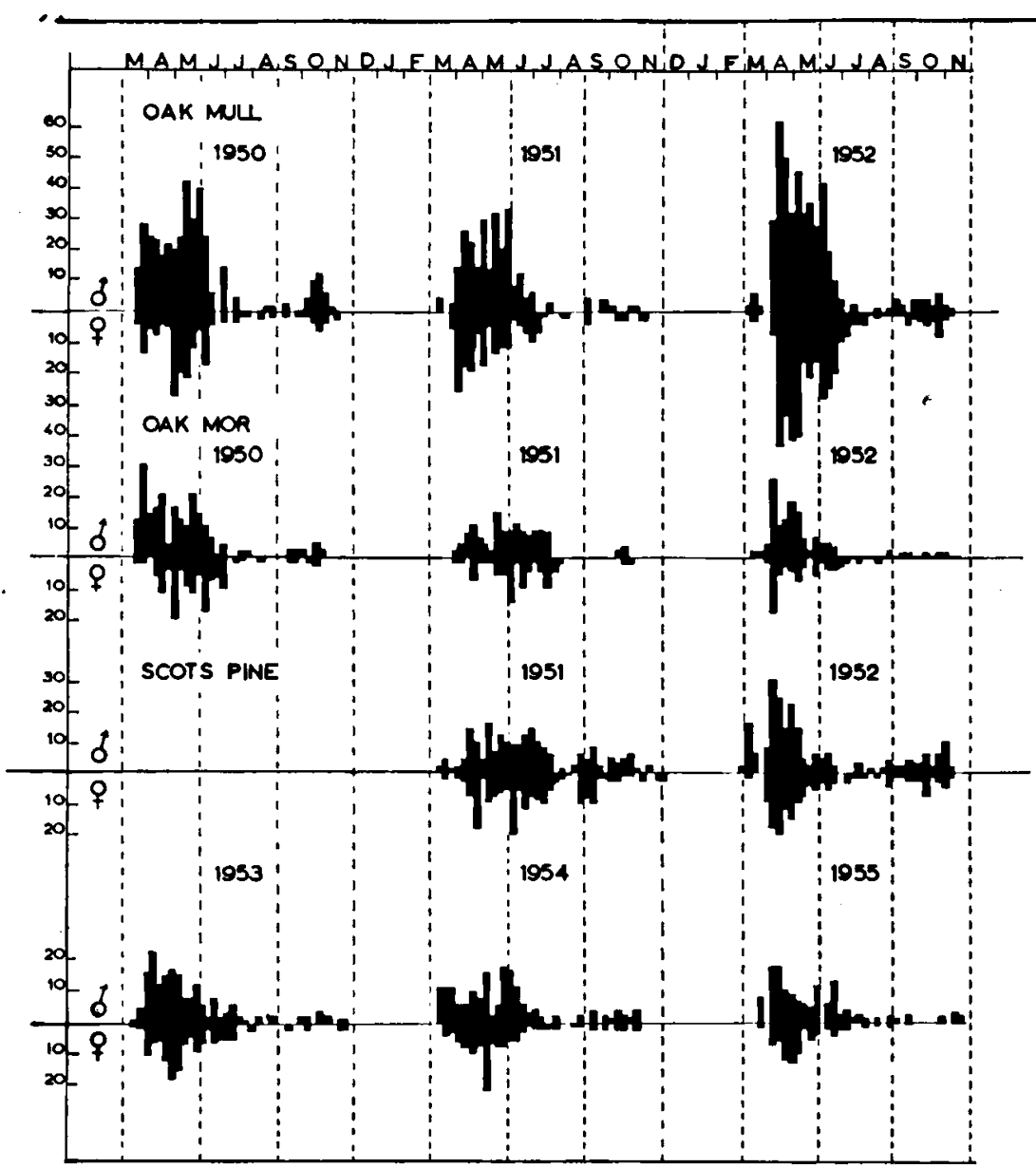

Fig. 1. Weekly captures of Pterostichus oblongopunctatus in two oakwoods (each 10 traps) and in a pine wood (20 traps).

primarily by changes in activity and secondarily by varied numbers of imagines. In most species it is clear that emergence occurs long before the period of highest catches. The small captures at the time of emergence and afterwards, are due to low activity.

The histograms may be considered to indicate the activity. The histogram of the weekly catches expressed as a percentage of the total capture throughout the year will be called an activogram.

Most histograms, and thus activograms too, show one or more curves. The shape of the curves may be attributed to two factors:

1. The varying time at which activity begins;

2. The length of the period of individual activity.

When the range of factor 1 is small and the individual activity short, a steep-sided, but short curve will result. With a large range and a long individual activity a slow-sided and long curve results etc.
Fig. 2 demonstrates the different theoretical shapes of the histograms for two ranges of beginning activity ( 3 and 7 weeks) and four different periods of individual activity (2, 3, 5 and 8 weeks). The population densities are the same (8 units in the diagram), a regular distribution in the beginning of activity is assumed, mortality and weather influences on activity are excluded. The total number caught during the activity period is proportionate to the length of the individual activity, the steepness of the curve is determined by the range in beginning activity.

Figures 3-5 give the average activograms of the carabids, other beetles and spiders. They are based on the total catches in the different areas during the years 1950 to 1954 inclusive and they represent the weekly percentage of males and females of the total catch. The total numbers of males and females are given for each species. In general those species caught in a lower number than 100 are omitted. 

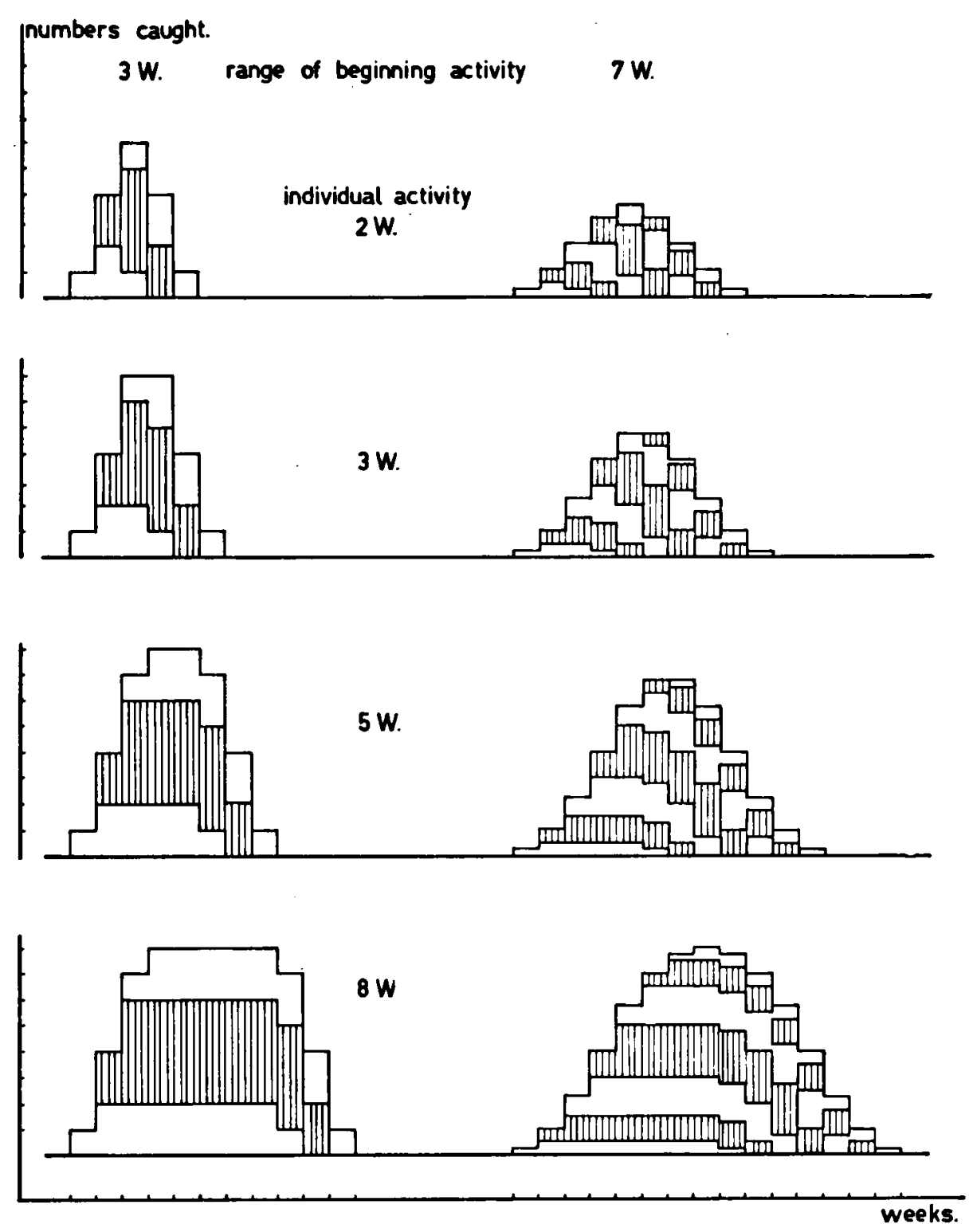

Fig. 2. Different shapes of histograms induced by different ranges of beginning activity ( 3 and 7 weeks) and varying length of the individual period of activity, $(2,3,5$ and 8 weeks). The numbers of animals becoming active in the first, second, third etc. week are represented by white and hatched columns alternatively.

\section{A. CARABIDS}

From the activograms it appears that the activity of most carabids is restricted to a part of the year. Only Notiophilus biguttatus F. and N. rufipes Curt. and perhaps also the other Notiophilus species occur throughout the year. But within this period of activity there is a considerable difference in its intensity. In nearly all species, maximum activity both of males and females occurs during the oviposition period: reproductive activity. With respect to the period of reproduction two types can be distinguished.

The first type is related to species that reproduce in spring and/or early summer. Their larvae occur in summer and emergence takes place in late summer and autumn. These species may properly be indicated as: spring-breeding species with summer larvae.

The following species belong to this group: Cara- 
bus nemoralis Müll., Pterostichus oblongopunctatus F., $P$. angustatus Duft., $P$. strenuus Panz. In two species, $C$. nemoralis and $P$. oblongopunctatus, some mature eggs were observed in the ovaries in autumn. It is not known whether these animals belonged to the old or to the new generation. This exceptional behaviour of a very small number of the animals is reflected also by the finding of a pupa of $C$. nemoralis in spring and the exceptional occurrence of larvae of $P$. oblongopunctatus in winter, both mentioned by LiNDROTH (1945).

The second type refers to species that reproduce in summer or late summer and autumn. Their larvae live in autumn, winter and spring and emergence generally occurs in early summer. They are called: summer-breeding species with winter larvae: Carabus problematicus Herbst, $C$. violaceus purpurascens F., Cychrus rostratus L., Pterostichus madidus F., $P$. niger Schall., Calathus micropterus Duft., C. erratus Sahlb., C. fuscipes Goeze, C. melanocephalus L., Amara anthobia Villa. In this group active imagines are present before emergence of the new generation. They have passed the winter as imagines and have probably reproduced the preceding year. In most cases developing ovaries were observed and oviposition will likely occur at the same time as the oviposition of the new generation. Only in a few cases mature eggs were observed before that time. In the species with summer larvae it is difficult to find out whether the reproducing animal is of the new or of the previous generation. The recapture of individuals of Pterostichus oblongopunctatus marked during the preceding reproductive period, demonstrates the longevity of this species.

Some species are not included in the above mentioned types. Abax ater Villa shows two distinct periods of emergence: mature eggs occur throughout the period of activity and larvae occur throughout the year. Evidently part of the population reproduces in spring and has summer larvae and the other part reproduces in summer and has winter larvae.

It is more difficult to interpret the results of Notio-
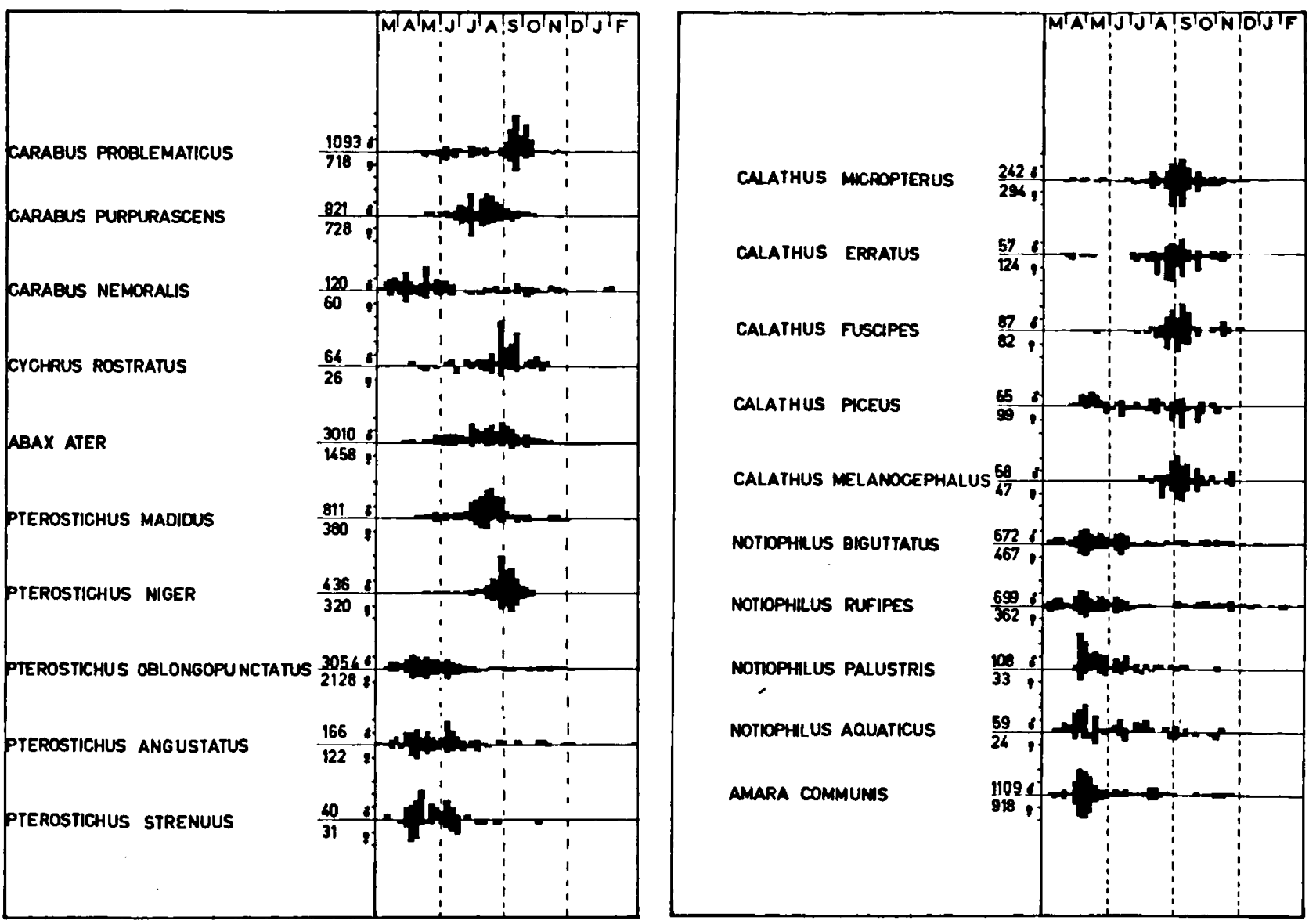

Fig. 3. Average activogram of the main forest carabids. Units on ordinate five percents of total capture. 


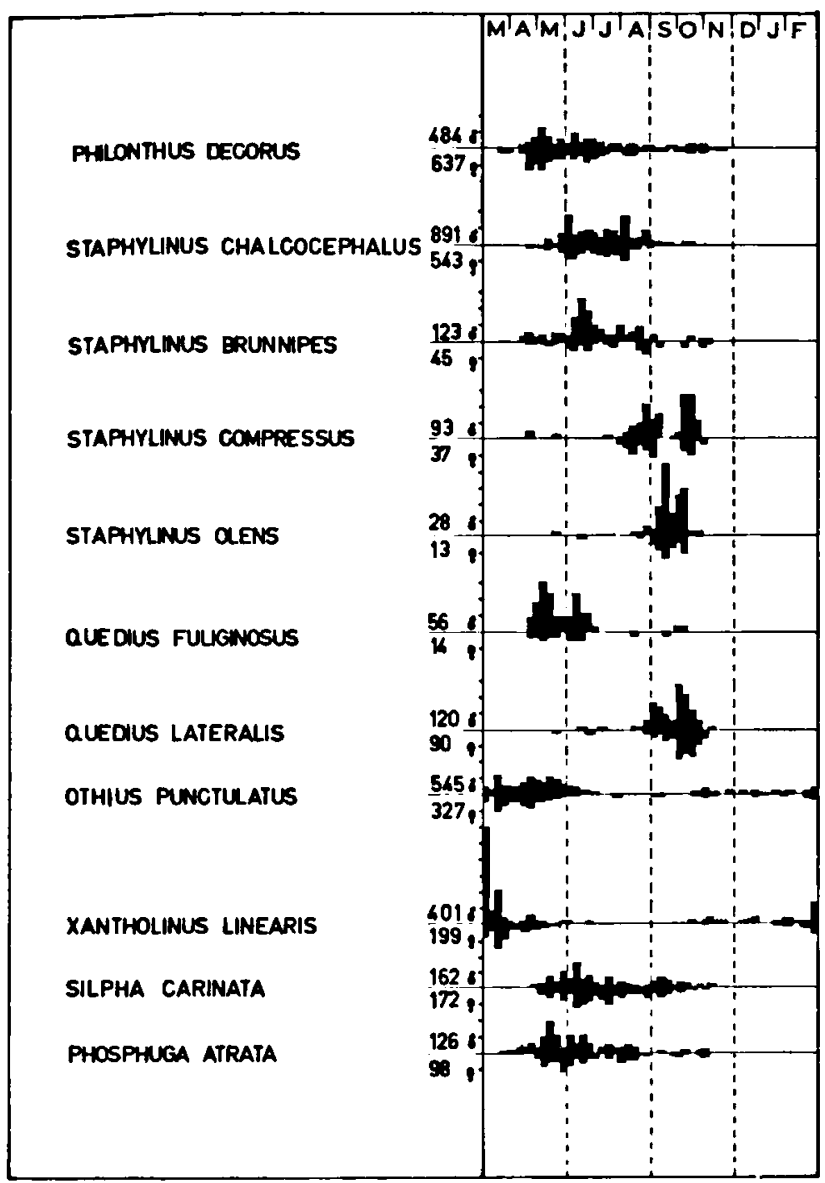

Fig. 4. Average activograms of staphylinids and silphids. Units on ordinate five percents of total capture.

philus species, $N$. palustris Duft, and $N$. aquaticus L., since they were caught in rather small numbers. Highest activity occurs in spring and early summer. Mature eggs, however, were observed in the ovaries almost throughout the year and emergence was demonstrated only in one year in early summer. It seems likely that emergence generally escapes observation owing to the minor activity of newly emerged animals. The prolonged period of reproduction probably may be due to the small number of mature eggs present at any time in a female. The maximum number of relatively large eggs found in any female of these species was 3, whereas in Carabus, Abax and the large and medium sized Pterostichus species this maximum was between 20 and 30 .

Of the species studied, Amara communis Panz. is the only one that gave discordant results in the different years. It was remarkable that in this case highest activity did not coincide with reproduction.

Comparison of the activograms of related species

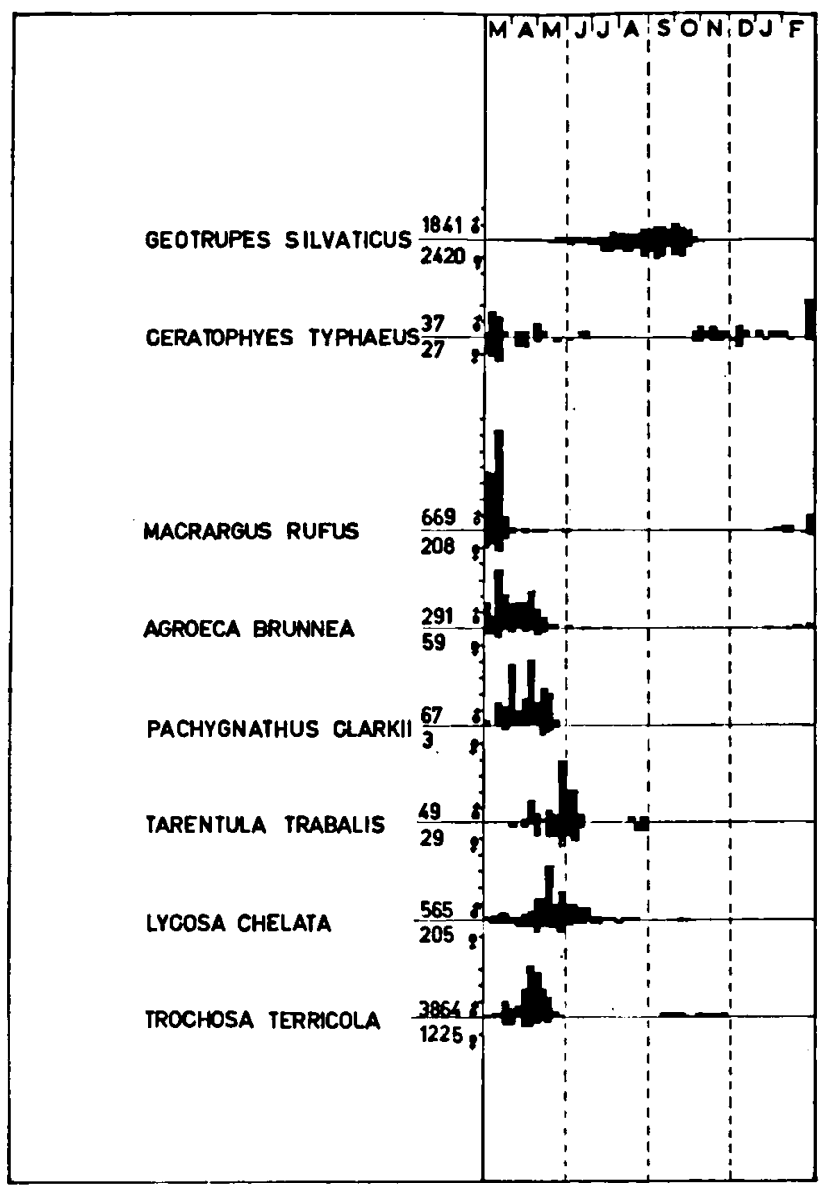

Fig. 5. Average activograms of dor-beetles and spiders. Units on ordinate five percents of total capture.

shows that related species have different periods of peak activity and that the successive peaks of the various species together extend throughout the whole growing season, e.g. Carabus nemoralis-C. v. purpurascens-C. problematicus and Pterostichus oblongopunctatus-P. niger.-P. madidus. In Calathus and Notiophilus this alternation does not occur. As the feeding habits of these various Carabus species are probably very similar, this alternation may be of great ecological importance.

The shape of the curves during the reproductive period for the species with summer larvae is wholly different from the shape of those with winter larvae. In the first group the curve is rather steep, but low and long, indicating a short period during which activity at first begins, but a long individual activity. In the second type the curve is steep, high and short, indicating a small range also, but a short individual activity.

It may be observed that in most species the num- 
ber of females is much lower than the number of males. Exceptions are the Calathus species, where especially in $C$. erratus the females outnumber the males by far. Of course this proportion may not represent a true sex ratio, since males and females may be active to a different degree. Males predominate most in the first weeks of the reproductive periodespecially in the spring-breeding species-whereas females are more numerous at the end of this period. These facts, may be attributed to the mate-searching activity of the males in the first case and to the oviposition activity of the females in the latter.

\section{B. OTHER BEETLES}

The staphylinids, caught in the traps, belonged to the larger species. Also in these species the greatest activity occurs during the oviposition period. Newly emerged animals could only be distinguished in one case and larvae of only three species were taken. So the life cycle is mainly based on the time of the oviposition period and remains in some cases somewhat doubtful.

Fig. 4 shows that three types can be discerned:

1. Species with summer larvae. Activity already begins in autumn but remains very low until the beginning of spring. Eggs can be observed in the ovarioles but they are soft and white. At the beginning of spring the eggs are mature, and activity, both of males and females, increases as in Othius punctulatus Goeze and Xantholinus linearis Ol. Philonthus decorus Grav. may perhaps also be classed in this group. At the end of August a soft specimen was observed. In winter this species is not active and reproduction starts about a month later than in the previous species. Quedius fuliginosus Grav. may also belong to this group but data are not more than suggestive.

2. Species with larvae in summer and autumn. Reproduction takes place in summer. It is not known whether the new generation emerges in autumn or in spring. The first possibility is more probable since mature eggs are present immediately after the beginning of activity: Staphylinus chalcocephalus F. and Staphylinus brunnipes F.

3. Species with winter larvae. Reproduction takes place in late summer and autumn. Larvae are active throughout winter and disappear in early spring. Newly emerged animals were not observed but probably occur in early summer. Apparently the surface activity of newly emerged animals is very low. To this group belong: Staphylinus compressus Marsh, Staphylinus olens Müll. and Quedius lateralis Grav.

It seems that in this family too the species reproducing in spring and summer have a rather long individual period of activity, whereas those reproducing in autumn have a short one with activity commencing during only a very restricted period. An exception is Xantholinus linearis with a very high and short curve in spring. The periods of peak activity alternate rather distinctly in the species Staphylinus brunnipes, S. chalcocephalus and S. compressus. With exception of Philonthus decorus, mailes outnumber the females in the captures again.

The two silphids, Silpha carinata Herbst. and Phosphuga atrata L. show similar activograms. They have summer larvae. Their reproductive period is rather late compared with the spring-breeding carabids and staphylinids. After this period activity remains rather high. Emergence of the new generation produces some increase in the catches in September.

Geotrupes silvaticus Panz. and Ceratophyus typhaeus L. are species with life-habits which are quite different from the preceding species. They are not predators but feed on dung, toadstools etc. No large numbers were caught during their reproductive period. The captures of Geotrupes silvaticus increased after the oviposition period. Since no newly emerged animals are present, this increment must probably be attributed to increased surface activity (increased searching for food). In the middle of August the numbers taken increase again, but now many soft animals are present and this increment is due to emergence of the new generation. In Ceratophyus typhaeus oviposition takes place from November till March. No soft animals were observed. It is doubtful whether the peak in March has any real significance in view of the small numbers taken.

\section{SPIDERS}

The histograms of the species given are real activograms. They are caused by the very intense mating activity of the males. After the mating period, the samples consist mainly of females bearing eggs (Lyco- 
sidae). In Trochosa terricola Thor, by far the most numerous species, half grown specimens are caught from spring until the autumn. This suggests a development to maturity of more than one year.

In general the shape of the curves is rather short and high, indicating a short individual activity and a small range. Males outnumber females by far in the samples. The three lycosid species show separate periods of peak activity, but they cover only the first half of the growing-season.

\section{DISCUSSION}

\section{A. COMPARISON WITH OTHER RESULTS}

LARSSON published in 1939 a paper on types in Danish carabids with respect to their development. This study is based on collections of larvae and imagines mainly from Denmark. Two main types are distinguished: spring-breeding species and autumnbreeding species. In the first type several subtypes are discerned with respect to the activity of the young generation in autumn. According to LArsson nearly all adults die after reproduction and so the spring-breeding species only hibernate as young imagines. In the autumn-breeding species the adults may withstand the severe winter conditions but die in spring or summer before the young generation emerges. As stated in the previous chapter several individuals of the spring-breeding Pterostichus oblongopunctatus, which were marked and released during the reproductive period were recaptured the next year and thus the first assumption does not hold, at least in the Netherlands. There are also objections to the second assumption. Kern (1912) showed by histological investigation that in Carabus species a second reproduction is probable and this conclusion was affirmed by Grubert (1956) in four Calathus species. The presence of small ovarioles in Carabus problematicus just after hibernation also points to this possibility, but it is not certain that these animals developed eggs in the preceding year. Though the field observations are not convincing in themselves, in connection with the findings of KERN it seems very likely that some of the autumn-breeders, perhaps a rather small proportion, reproduce again the following year. Probably this is also the case with Pterostichus oblongopunctatus (spring-breeder), but the ovaria of the hibernating females were not dissected.

LiNDROTH (1949) distinguished the same two types as LARSSON did, but preferred to denote them as imago-hibernators and larva-hibernators since the reproduction of the first group in Sweden generally occurred not before summer (June) and the stage in which hibernation takes place is of great ecological importance. However, among the larva-hibernators some of the imagines also hibernate and so I prefer to denote them as species with summer larvae and winter larvae respectively. Moreover this way of describing indicates at which time the most susceptible stage, the larva, occurs.

Both LARSSON and LindQuist give monthly frequencies of catches in Denmark and Sweden respectively. The developmental type was assessed from these frequency curves and the occurrence of larvae, immature adults etc.

Their results are compared with those of this study in Table 1. The Roman numerals giving the months with the highest frequencies, the month with the highest being in italics. In general there is a good agreement as to the type of each species. Only in the case of Carabus problematicus and Calathus micropterus the differences are appreciable. C. problematicus has summer larvae in Sweden and in Denmark and has winter larvae in the Netherlands. Calathus micropterus is a typical summer-breeder with winter larvae in this country. LARSSON found this to be the case in Denmark as well, but believes that some reproduction occurs in spring. In Sweden spring-breeding with summer larvae is normal. The same tendency, though in more moderate form is seen in Carabus violaceus, Calathus melanocephalus and possibly in Cychrus rostratus in which species a part of the population in Sweden belongs to the summer larvae type (= imago hibernator), whereas in Denmark and the Netherlands only the other type occurs. It is remarkable that the opposite situation, i.e. species with winter larvae in Sweden but summer larvae in this country, does not occur in this material though this change of reproductive type would be more understandable in connection with the shorter summers in Scandinavia.

If we take the months with high frequencies, as 


\begin{tabular}{|c|c|c|c|}
\hline & $\begin{array}{c}\text { Sweden } \\
\text { (Lindroth '45) }\end{array}$ & $\begin{array}{c}\text { Denmark } \\
\text { (Larsson '39) }\end{array}$ & Netherlands \\
\hline $\begin{array}{l}\text { Carabus nemoralis Ill. } \\
\text { *Carabus problematicus Herbst. } \\
\text { Carabus violaceus L. } \\
\text { *Carabus violaceus purpurascens F. } \\
\text { *Cychrus rostratus L. } \\
\text { Abax ater Villa. } \\
\text { Pterostichus madidus F. } \\
\text { *Pterostichus niger Schall. } \\
\text { Pterostichus oblongopunctatus F. } \\
\text { Pterostichus angustatus Duft. } \\
\text { Pterostichus strenuus Panz } \\
\text { *Calathus micropterus Duft. } \\
\text { *Calathus erratus Sahlb. } \\
\text { *Calathus fuscipes Goeze. } \\
\text { Calathus piceus Marsh } \\
\text { *Calathus melanocephalus L. }\end{array}$ & $\begin{array}{l}\text { V-VI } \\
V \text {-VI-VIII } \\
\text { VI-VII-VIII } \\
\text { VI-VII-VIII } \\
\text { V-VI-VII-VIII } \\
\text { V-VI } \\
\text { VI } \\
\text { V-VI } \\
\text { VI } \\
\text { VI-VII-VIII } \\
\text { VI-VII-VIII } \\
\text { VI-VII }\end{array}$ & $\begin{array}{l}I V \text {-V, VIII } \\
V, \text { VII } \\
\text { VI-VII-VIII } \\
\text { VII-VIII } \\
\text { V-IX } \\
\text { VII-VIII } \\
\text { IV, (IX) } \\
\text { IV } \\
\text { IV-X } \\
\text { IV, VII-VIII } \\
\text { VII-VIII } \\
\text { VIII-IX } \\
\text { VI-VII-VIII }\end{array}$ & $\begin{array}{l}\text { III-IV-V } \\
\text { IX } \\
\text { VII-VIII } \\
\text { VIII-IX } \\
\text { VI-IX } \\
\text { VII-VIII } \\
\text { VIII-IX } \\
\text { IV-V-VI } \\
\text { IV-V-VI } \\
\text { IV-V-VI } \\
\text { VIII-IX } \\
\text { VIII-IX } \\
\text { VIII-IX } \\
\text { V, VIII-IX } \\
\text { VIII-IX }\end{array}$ \\
\hline
\end{tabular}

TABle 1. Months of high capture frequencies of some forest carabids in Sweden and Denmark (months with highest frequencies in Italics) compared with peak captures of the same species in the Netherlands. Species with winterlarvae in the Netherlands are indicated by an asterisk.

given by Lindroth and LARsson (Table 1), to correspond with highest activity and reproductive period, it appears that in most of the species with winter larvae the period of highest activity is earlier in Sweden than in Denmark and in Denmark earlier than in the Netherlands: Cychrus rostratus, Pterostichus niger, Calathus erratus, Calathus fuscipes.

This possibly may be connected with earlier winter in the northern countries resulting in an earlier reproductive period. This gives the new generation an opportunity to reach a stage in which it can possibly better withstand the severe winter conditions. Should this interpretation be true, the above mentioned species, having summer larvae in Scandinavia and winter larvae here, should be considered to have reached the best adjustment to the Scandinavian climatological conditions by moving forward their period of reproduction to such an extent that their offspring can reach maturity before winter. The reverse is seen in the summer larvae species Carabus nemoralis, Pterostichus oblongopunctatus, Pterostichus angustatus and Pterostichus strenuus. Here the period of reproduction is earlier in the southern countries, doubtlessly in connection with the earlier spring.

\section{B. THE LIFE CYCLE AND ACTIVITY FLUCTUATION OF CARABUS PROBLEMATICUS HERBST}

The activogram of Carabus problematicus in Fig. 3 shows that before the period of high activity, starting at about the middle of August, there is a long period (April-August) during which a rather small number of beetles is caught weekly. The first catches (AprilJune) consist of hibernating imagines. They form the first inconspicuous peak in early June. From the middle of June the new generation emerges and activity goes on until the first part of August. This produces the second peak in July. Activity is only due to feeding, mating was not observed and the gonads were not yet mature. In the middle of August there is a distinct minimum in the catches, followed by a period of high captures indicating high activity during September. The gonads are now mature; copulations frequently occur and eggs are deposited. First instar-larvae occur from October until April, indicating a very slow development during winter; the 2nd instars occur from November (very small numbers) until the middle of May, 3rd instars do not appear before April and they disappear at the end of May. Evidently the duration of each instar is determined largely by temperature. Minimum time for each stage-with exception of the 2nd instar-seems to be about one month.

It was stated above (p. 81) that the shape of the 


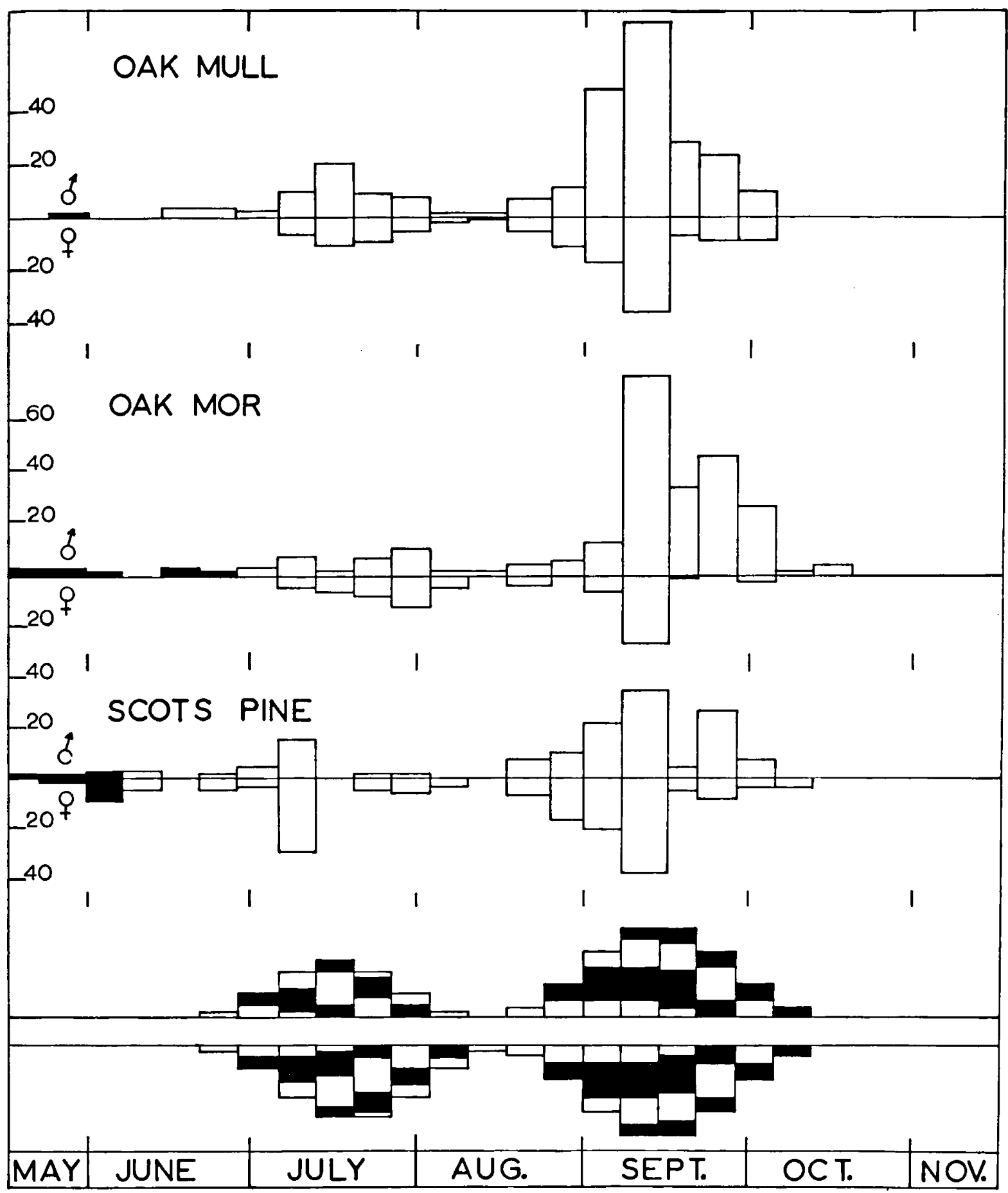

Fig. 6. Histograms from capture data 1951 and hypothetical histogram of Carabus problematicus Herbst. Explanation in text. 
histograms is caused by the length of the period during which activity first begins and by the length of the individual activity. This was substantiated by observations on the occurrence and activity of this species in 1951. The hibernating imagines occurred from the middle of May and were caught in small numbers only. From terrarium observations at this time it appeared that their activity is slight, that they retire under the ground cover after about one week and that they are re-activated in the latter part of August.1)

Newly emerged animals with soft elytra occurred from mid June until the end of July and thus activity commenced over a period of 5 weeks. Terrarium observations demonstrated that these animals were very active only for a few weeks after emergence: males about two weeks, females about three weeks. After that period activity diminished greatly and the animals remained nearly motionless under ground cover for several weeks. A hypothetical histogram for this period, based on these facts, is given in Fig. 6 (lowest histogram, first curve), assuming a normal distribution of the occurrence of newly activated animals in the successive weeks.

Animals becoming active in the first week and remaining active for two weeks may be caught in the first three weeks but the numbers caught in the second week are twice as high as those caught in the first and third week (white columns). The same holds for animals becoming active in the second week, but their numbers are larger than the numbers of animals becoming active in the first week according to the normal distribution (black columns). The numbers of animals becoming active in the third week are larger again (white), but from hereon the numbers decrease. Adding all numbers of animals that may be caught gives a curve with a peak which corresponds rather good with those of the field data (upper three histograms, white columns) and a length, which also corresponds with the length of the field curves.

The earlier occurrence in the pinewood has to be ascribed to microclimatological influences and will be referred to in the last section. The field data show that first re-activation occurs about 7-8 weeks after the first appearance of the newly emerged animals and the same distance is seen between peak captures in the first and the second activity period. Assuming, on grounds given above, that in the field young imagines also have an activity period of 2-3 weeks, it seems that they have after this a period of inactivity lasting about 5 weeks.

In terraria this period was about 3 weeks but artificial circumstances (higher temperature and mutual disturbance of the animals kept) may be responsible for this. The last emerged imagines had an even shorter inactivity period and very possibly this also holds true in the field. When the animals are active again the reproductive organs are mature and copulations are observed. Dispersion in re-activation and in individual activity period gives rise again to a rather steep and high curve. In all cases-also in other years-the captures are much higher now than in the activity period of the immature individuals. This may be attributed in the first place to a longer individual activity period. Supposing the range in the re-activation to be four weeks, the animals will have an individual activity period of four weeks, to cover the period of the main capture (see hypothetical histogram for the mature activity period in Fig. 6). By this the takings of males and females in the second activity period should be about 2.0 and 1.3 times higher respectively than in the first period. In fact the September curves are not only longer but also much higher than the July ones. Almost twice as many females are taken $(229: 123=1.9)$ and the male capture is about fivefold (489: $102=4.8$ ). This certainly must be attributed to higher activity (intensity or duration per day) caused by mating. Evidently in search for mates, males are more activated than females.

There is a second, though less important, reason why catches in the second activity period are higher than in the first. Whereas the September curve consists wholly of young imagines, the July one, however, includes also hibernated imagines (black columns in the upper three histograms). These latter were active before July (black columns upper histograms) but inactive at the time the young imagines emerged. At the reproductive time they were re-activated. It was not possible to estimate the proportion of these old animals. The low numbers caught in June suggest that the proportion is small.

It is only in this species that immature and mature activity curves are clearly separated, which is due to the fact that the individual resting period is so long and that activity is so low during this period. In the other summer breeding carabids e.g. Carabus v. purpurascens, Cychrus rostratus, Pterostichus madidus and Pterostichus niger, the curves merge into each other. In the first species it was stated that the resting period was much shorter and the animals maintained some activity.

1) These terrarium observations were made indoors in a large square tray of about 1 sq. meter by Miss C. A. MELCHOR. 


\section{FLUCTUATIONS IN POPULATION DENSITY}

It is of interest to inquire to what extent these samples reflect fluctuations in population density. It was stated in the previous sections that the changing numbers from week to week are mainly caused by changing activity. If, however, we compare the total captures in successive years, the overall weather conditions compensate to a fair degree and it is supposed arbitrary that changes in total catches exceeding $25 \%$ are caused by higher or lower density.

A second difficulty arises from the fact that removal of the animals by sampling reduces population density to an unknown degree. In the first place it must be borne in mind that the traps are not attractive and thus the catching-capacity is proportional to the surface of the tins. At a mutual distance of 50 metres and a surface of $25 \times 25 \mathrm{~cm}$ the proportion of the "catching surface" to the surrounding area is $1: 40.000$, a ratio which strongly suggests that the traps have no deleterious effect on the surface fauna. In the second place it must be pointed out that the plots carrying the traps are surrounded by forest areas of about the same composition. The well known motive powers of these beetles, especially of the larger carabids and Geotrupes silvaticus, of which marked specimens were taken within a week about hundred metres from the point of release, provide the possibility of continuous immigration from the surroundings. If notwithstanding this, trapping would have had a deleterious influence, the numbers of species that showed a decrease in succeeding years, would have been larger than the number that increased or remained equal. It is shown in Table 2 that this was only the case in 1953. In this table the number of increasing, constant and decreasing species are given for the different years in the different areas. In the oakwood 26 species are concerned, in the pinewood 19 species. Cases in which the years' captures were 10 or less are placed in brackets. It may be concluded from this, that trapping does not result in an ever decreasing density of the species concerned. It is not possible to deduce from the available data to what extent this trapping technique influences the density since comparable data of captures from which the animals were released again

\begin{tabular}{|c|c|c|c|}
\hline & Increase & Constant & Decrease \\
\hline $\begin{array}{l}\text { Oak mull } \\
1950-51 \\
1951-52\end{array}$ & $\begin{array}{r}10(+1) \\
5(+1)\end{array}$ & $\begin{array}{r}8 \\
11\end{array}$ & $\begin{array}{l}4 \\
8(+1)\end{array}$ \\
\hline $\begin{array}{l}\text { Oak mor } \\
1950-51 \\
1951-52\end{array}$ & $\begin{array}{r}11(+1) \\
6(+3)\end{array}$ & $\begin{array}{l}5 \\
6(+1)\end{array}$ & $\begin{array}{l}4(+2) \\
9(+1)\end{array}$ \\
\hline $\begin{array}{l}\text { Pine (close } \\
1951-52 \\
1952-53 \\
1953-54 \\
1954-55\end{array}$ & $\begin{array}{l}7(+1) \\
3(+2) \\
4(+2) \\
9(+3)\end{array}$ & $\begin{array}{l}4(+1) \\
2(+2) \\
5(+3) \\
2\end{array}$ & $\begin{array}{l}6 \\
10 \\
4(+1) \\
3(+2)\end{array}$ \\
\hline $\begin{array}{l}\text { Pine (open } \\
\\
1951-52 \\
1952-53 \\
1953-54 \\
1954-55\end{array}$ & $\begin{array}{l}4(+1) \\
2 \\
3(+2) \\
7\end{array}$ & $\begin{array}{l}5 \\
5(+1) \\
4(+2) \\
2(+1)\end{array}$ & $\begin{array}{r}8(+1) \\
10(+1) \\
7(+1) \\
5(+4)\end{array}$ \\
\hline
\end{tabular}

TABLE 2. Frequency of the number of species showing increase, equal density or decrease in two successive years. 
are lacking and on the other hand trapping was not performed in enclosed areas. $\because \div$

In Table 3 the ratio for the catches from one year to the next is given for the different areas. Values based on captures of 10 or less are placed in brackets.

With exception of the 1955/54 ratio the extremes are 0.02 and 17.05 but $87 \%$ lies between 0.2 and $4.00,26 \%$ lies between 0.75 and 1.25 , the arbitrary limits for unchanged density; $34 \%$ of the values exceed 1.25 against $40 \%$ which are below 0.75 . It is evident from this too that there is no significant excess of ratios below 1, which should indicate a steady decrease by removal of the animals. It may be seen that both in the two oak plots and in the two pineplots the changes in each pair of plots are generally in the same direction. To 63 cases with corresponding development there were 11 cases with opposite tendency (ratio's 1955/54 and values in brackets not considered).

The highest increases took place in the year 1951 especially in the carabid species with winter larvae. It is not possible to trace the causes of this increase. Though there was no trapping in the pine forest in 1950 , the large numbers captured in 1951 suggest a high increase there as well and if this is true it is probable that climatic influences are involved. The winter of 1950-1951 was characterised by a normal autumn, a short frost period in December, followed by a mild winter and a normal spring. Before and after the frost period precipitation was above average. It may be assumed that these conditions were favourable for the development of winter larvae. Indeed numerous larvae of Carabus problematicus and Carabus v. purpurascens were taken, these being the only species in which the larvae are rather efficiently caught by the trapping technique used.

After the year of high density another mild winter followed with only a shorter and less severe frost period than in the preceding year. The captures of larvae were significantly larger than in the winter of $1950-51$, in the oakwood 88 and 26 resp. Following the high population density in 1951, the number of hibernating imagines in 1952 was relatively large and in the earlier species, $C$. $v$. purpurascens, large numbers of young imagines were taken. After the first week of July the catches of this species decreased abruptly. In the oak forest only some mature imagines were taken, in the pine forest these numbers were still large but yet small in comparison with the very large numbers of freshly emerged adults in this area.

The high total capture for 1952 in this area is caused by the very large number of freshly emerged animals caught up to the first week of July. The ratio of the total annual captures in this case gives a false impression of the change in population (1.35 in the closed and 1.46 in the open part). Based on the mature imagines this ratio more correctly may be evaluated as 0.48 and 0.36 respectively. In Carabus problematicus, normally somewhat later than the other species, only in oak-mull freshly emerged animals were caught in the first week of July. After that date in this area, as in the others, freshly emerged animals were taken only occasionally and mature animals were caught in small numbers compared with the preceding year.

It is evident from the foregoing that the sharp decrease in density from 1951-52 is not likely to be attributed to the high catches and thus to the removal of a large number of animals in 1951. If this had been the cause, the numbers of larvae would have been influenced and this apparently has not been the case. For the same reason the decrease in density can also not be ascribed to unfavourable conditions for larval development in winter. The sudden decrease in both species in all areas suggests deleterious meteorological influences in the first part of July. Possibly these were the very heavy rainfalls combined with high temperatures. The first may have been detrimental for the freshly emerged animals activated greatly by the exceptional high temperatures.

It is evident that the population changes differ widely in the different species. Nevertheless there is a closer conformity within the two developmental types. Thus the species with winter larvae show a significant increase from 1950 to 1951 (av. ratio 6.90) whereas the species with summer larvae remain at about the same level during that period (av. ratio 0.97 ). The following year produced a sharp decrease in the first group (av. ratio 0.36 ) but now the species with summer larvae show some increase (av. ratio 1.38). The Notiophilus species form a homogeneous group on themselves, with ratios of 1.18 and 2.10 respectively in the two years. This conformity in population changes within groups of the same developmental type suggests also a directing influence of meteorological factors on population density.

The year 1955 shows a distinct increase in several species in the closed part of the pinewood, and a decrease in the open part. This difference is caused by the fact that in the winter of 1954-55 the trees in the open part were felled. Although this may have influenced the adjacent parts to some degree, it seems probable that, without any alteration in the stand, the population changes would have been in the same direction as they were in the unaltered part. 


\begin{tabular}{|c|c|c|c|c|c|c|c|}
\hline & & 1951 & $\frac{1951}{1950}$ & $\frac{1952}{1951}$ & $\frac{1953}{1952}$ & $\frac{1954}{1953}$ & $\frac{1955}{1954}$ \\
\hline $\begin{array}{c}\text { Notiophilus } \\
\text { aquaticus }\end{array}$ & $\begin{array}{l}\mathbf{c} \\
\mathbf{d}\end{array}$ & $\begin{array}{r}7 \\
16\end{array}$ & & $\begin{array}{r}3.00 \\
.50\end{array}$ & $\begin{array}{l}(.43) \\
(.88)\end{array}$ & $\begin{array}{r}(1.00) \\
(.29)\end{array}$ & $\begin{array}{r}(.33) \\
(7.50)\end{array}$ \\
\hline $\begin{array}{l}\text { Staphylinus } \\
\text { chalcocephalus }\end{array}$ & $\begin{array}{l}\mathbf{a} \\
\mathbf{b} \\
\mathbf{c} \\
\mathbf{d}\end{array}$ & $\begin{array}{r}81 \\
578 \\
78 \\
11\end{array}$ & $\begin{array}{l}1.29 \\
1.56\end{array}$ & $\begin{array}{l}.46 \\
.30 \\
.35 \\
.36\end{array}$ & $\begin{array}{l}.04 \\
.00\end{array}$ & $(2.00)$ & $(5.00)$ \\
\hline $\begin{array}{c}\text { Staphylinus } \\
\text { brunnipes }\end{array}$ & $\begin{array}{l}\mathbf{a} \\
\mathbf{b}\end{array}$ & $\begin{array}{l}26 \\
35\end{array}$ & $\begin{array}{l}1.04 \\
1.94\end{array}$ & $\begin{array}{l}1.04 \\
1.06\end{array}$ & & & \\
\hline $\begin{array}{l}\text { Staphylinus } \\
\text { compressus }\end{array}$ & $\begin{array}{l}\mathbf{a} \\
\mathbf{b}\end{array}$ & $\begin{array}{l}9 \\
3\end{array}$ & $\begin{array}{l}.09 \\
.19\end{array}$ & $\begin{array}{l}(.11) \\
(.33)\end{array}$ & & & \\
\hline $\begin{array}{l}\text { Quedius } \\
\text { fuliginosus }\end{array}$ & $\begin{array}{l}\mathbf{a} \\
\mathbf{b}\end{array}$ & $\begin{array}{r}19 \\
2\end{array}$ & $\begin{array}{l}.79 \\
. .29)\end{array}$ & $\begin{array}{c}.79 \\
(1.50)\end{array}$ & & & \\
\hline $\begin{array}{l}\text { Quedius } \\
\text { lateralis }\end{array}$ & $\begin{array}{l}\mathbf{a} \\
\mathbf{b}\end{array}$ & $\begin{array}{l}13 \\
45\end{array}$ & $\begin{array}{l}.26 \\
.85\end{array}$ & $\begin{array}{l}.87 \\
.85\end{array}$ & & & \\
\hline $\begin{array}{c}\text { Philonthus } \\
\text { decorus }\end{array}$ & $\begin{array}{l}\mathbf{a} \\
\mathbf{b}\end{array}$ & $\begin{array}{r}219 \\
3\end{array}$ & $\begin{array}{l}1.01 \\
(.43)\end{array}$ & $\begin{array}{c}3.03 \\
(4.00)\end{array}$ & & & \\
\hline $\begin{array}{l}\text { Othius } \\
\text { punctulatus }\end{array}$ & $\begin{array}{l}\text { a } \\
\mathbf{b} \\
\mathbf{c} \\
\mathbf{d}\end{array}$ & $\begin{array}{l}70 \\
84 \\
46 \\
26\end{array}$ & $\begin{array}{l}1.56 \\
1.06\end{array}$ & $\begin{array}{r}1.00 \\
1.38 \\
.89 \\
.54\end{array}$ & $\begin{array}{l}1.64 \\
1.62\end{array}$ & $\begin{array}{l}.29 \\
.21\end{array}$ & $\begin{array}{l}.07 \\
(.22)\end{array}$ \\
\hline $\begin{array}{l}\text { Silpha } \\
\text { carinata }\end{array}$ & $\begin{array}{l}\mathbf{a} \\
\mathbf{b} \\
\mathbf{c} \\
\mathbf{d}\end{array}$ & $\begin{array}{r}21 \\
79 \\
18 \\
4\end{array}$ & $\begin{array}{l}4.20 \\
2.26\end{array}$ & $\begin{array}{c}1.33 \\
.58 \\
1.72 \\
(4.00)\end{array}$ & $\begin{array}{l}.55 \\
.50\end{array}$ & $\begin{array}{l}1.00 \\
1.00\end{array}$ & $\begin{array}{l}1.24 \\
(.25)\end{array}$ \\
\hline $\begin{array}{l}\text { Phosphuga } \\
\text { atrata }\end{array}$ & $\begin{array}{l}\mathbf{a} \\
\mathbf{b}\end{array}$ & $\begin{array}{l}44 \\
46\end{array}$ & $\begin{array}{l}1.83 \\
1.05\end{array}$ & $\begin{array}{l}.82 \\
.65\end{array}$ & & & \\
\hline $\begin{array}{l}\text { Geotrupes } \\
\text { silvaticus }\end{array}$ & $\begin{array}{l}a \\
b \\
c \\
d\end{array}$ & $\begin{array}{r}44 \\
1417 \\
300 \\
42\end{array}$ & $\begin{array}{r}.77 \\
2.24\end{array}$ & $\begin{array}{r}.64 \\
.91 \\
.78 \\
1.29\end{array}$ & $\begin{array}{l}.15 \\
.24\end{array}$ & $\begin{array}{r}1.35 \\
.92\end{array}$ & $\begin{array}{l}3.87 \\
1.00\end{array}$ \\
\hline $\begin{array}{c}\text { Trochosa } \\
\text { terricola }\end{array}$ & $\begin{array}{l}a \\
b \\
c \\
d\end{array}$ & $\begin{array}{l}137 \\
200 \\
919 \\
493\end{array}$ & $\begin{array}{l}.50 \\
.61\end{array}$ & $\begin{array}{r}1.24 \\
1.31 \\
.78 \\
.72\end{array}$ & $\begin{array}{l}.65 \\
.85\end{array}$ & $\begin{array}{l}.53 \\
.65\end{array}$ & $\begin{array}{l}2.55 \\
1.83\end{array}$ \\
\hline $\begin{array}{l}\text { Lycosa } \\
\text { chelata }\end{array}$ & $\begin{array}{l}a \\
b \\
c \\
d\end{array}$ & $\begin{array}{r}20 \\
135 \\
12 \\
40\end{array}$ & $\begin{array}{l}.31 \\
.69\end{array}$ & $\begin{array}{r}1.25 \\
1.47 \\
3.08 \\
.75\end{array}$ & $\begin{array}{l}1.49 \\
2.53\end{array}$ & $\begin{array}{l}.02 \\
.05\end{array}$ & $\begin{array}{l}(26.00) \\
(15.00)\end{array}$ \\
\hline $\begin{array}{r}\text { Tarentula } \\
\text { trabalis }\end{array}$ & $\begin{array}{l}\mathbf{a} \\
\mathbf{b}\end{array}$ & $\begin{array}{r}9 \\
18\end{array}$ & $\begin{array}{c}(4.50) \\
.82\end{array}$ & $\begin{array}{r}.77 \\
1.11\end{array}$ & & & \\
\hline
\end{tabular}

TABLE 3. Ratio's of successive year captures in different plots.

$a=$ oak mull

b $=$ oak mor

c $=$ pine (closed part)

$\mathrm{d}=$ pine (open part)

The total capture of 1951 is given in the first column. 


\begin{tabular}{|c|c|c|c|c|c|c|c|}
\hline & & 1951 & $\frac{1951}{1950}$ & $\frac{1952}{1951}$ & $\frac{1953}{1952}$ & $\frac{1954}{1953}$ & $\frac{1955}{1954}$ \\
\hline $\begin{array}{l}\text { Carabus } \\
\text { problematicus }\end{array}$ & $\begin{array}{l}a \\
b \\
c \\
d\end{array}$ & $\begin{array}{l}371 \\
314 \\
126 \\
142\end{array}$ & $\begin{array}{l}1.98 \\
1.77\end{array}$ & $\begin{array}{l}.29 \\
.17 \\
.40 \\
.41\end{array}$ & $\begin{array}{l}.80 \\
.64\end{array}$ & $\begin{array}{l}1.54 \\
1.84\end{array}$ & $\begin{array}{r}1.24 \\
.47\end{array}$ \\
\hline $\begin{array}{l}\text { Carabus v. } \\
\text { purpurascens }\end{array}$ & $\begin{array}{l}a \\
b \\
c \\
d\end{array}$ & $\begin{array}{l}194 \\
297 \\
192 \\
114\end{array}$ & $\begin{array}{l}11.41 \\
12.38\end{array}$ & $\begin{array}{c}.18 \\
.16 \\
(1.35) .48 \\
(1.46) .36\end{array}$ & $\begin{array}{l}.07 \\
.20\end{array}$ & $\begin{array}{r}1.88 \\
.85\end{array}$ & $\begin{array}{r}7.69 \\
.53\end{array}$ \\
\hline $\begin{array}{l}\text { Carabus } \\
\text { nemoralis }\end{array}$ & $\begin{array}{l}\mathrm{a} \\
\mathrm{b}\end{array}$ & $\begin{array}{l}49 \\
15\end{array}$ & $\begin{array}{l}1.22 \\
1.25\end{array}$ & $\begin{array}{r}1.16 \\
.47\end{array}$ & & & \\
\hline $\begin{array}{l}\text { Cychrus } \\
\text { rostratus }\end{array}$ & $\begin{array}{l}\mathbf{a} \\
\mathbf{b}\end{array}$ & $\begin{array}{r}36 \\
9\end{array}$ & $\begin{array}{l}3.00 \\
(1.50)\end{array}$ & $\begin{array}{l}.53 \\
(.89)\end{array}$ & & & \\
\hline$\underset{\text { ater }}{\text { Abax }}$ & $\begin{array}{l}\mathrm{a} \\
\mathrm{b}\end{array}$ & $\begin{array}{r}1278 \\
896\end{array}$ & $\begin{array}{l}2.20 \\
1.70\end{array}$ & $\begin{array}{l}.60 \\
.38\end{array}$ & & & \\
\hline $\begin{array}{l}\text { Pterostichus } \\
\text { madidus }\end{array}$ & $\begin{array}{l}\mathbf{a} \\
\mathbf{b}\end{array}$ & $\begin{array}{r}46 \\
704\end{array}$ & $\begin{array}{r}.92 \\
3.81\end{array}$ & $\begin{array}{l}.28 \\
.20\end{array}$ & & & \\
\hline $\begin{array}{l}\text { Pterostichus } \\
\text { niger }\end{array}$ & $\begin{array}{l}\mathrm{a} \\
\mathrm{b}\end{array}$ & $\begin{array}{l}358 \\
239\end{array}$ & $\begin{array}{r}17.05 \\
8.85\end{array}$ & $\begin{array}{l}.20 \\
.17\end{array}$ & & & \\
\hline $\begin{array}{l}\text { Pterostichus } \\
\text { oblongopunctatus }\end{array}$ & $\begin{array}{l}a \\
b \\
c \\
d\end{array}$ & $\begin{array}{l}432 \\
198 \\
287 \\
463\end{array}$ & $\begin{array}{l}.78 \\
.61\end{array}$ & $\begin{array}{r}1.90 \\
.92 \\
1.56 \\
.66\end{array}$ & $\begin{array}{l}.63 \\
.96\end{array}$ & $\begin{array}{r}.82 \\
1.14\end{array}$ & \\
\hline $\begin{array}{l}\text { Pterostichus } \\
\text { angustatus }\end{array}$ & $\begin{array}{l}\text { c } \\
\text { d }\end{array}$ & $\begin{array}{l}16 \\
26\end{array}$ & & $\begin{array}{l}2.50 \\
1.04\end{array}$ & $\begin{array}{l}1.38 \\
1.22\end{array}$ & $\begin{array}{r}.89 \\
1.00\end{array}$ & $\begin{array}{l}1.59 \\
3.70\end{array}$ \\
\hline $\begin{array}{l}\text { Pterostichus } \\
\text { strenuus }\end{array}$ & $\begin{array}{l}\text { a } \\
\mathbf{b}\end{array}$ & $\begin{array}{r}32 \\
5\end{array}$ & & $\begin{array}{c}.78 \\
(1.80)\end{array}$ & & & \\
\hline $\begin{array}{l}\text { Calathus } \\
\text { micropterus }\end{array}$ & $\begin{array}{l}c \\
\text { d }\end{array}$ & $\begin{array}{r}43 \\
110\end{array}$ & & $\begin{array}{l}.63 \\
.37\end{array}$ & $\begin{array}{l}.85 \\
.80\end{array}$ & $\begin{array}{l}2.56 \\
5.06\end{array}$ & $\begin{array}{l}.36 \\
.22\end{array}$ \\
\hline $\begin{array}{l}\text { Calathus } \\
\text { erratus }\end{array}$ & $\begin{array}{l}\text { c } \\
\text { d }\end{array}$ & $\begin{array}{l}15 \\
61\end{array}$ & & $\begin{array}{l}.27 \\
.46\end{array}$ & $\begin{array}{c}(1.25) \\
.72\end{array}$ & $\begin{array}{l}(.80) \\
.25\end{array}$ & $\begin{array}{r}(8.00) \\
(12.00)\end{array}$ \\
\hline $\begin{array}{l}\text { Calathus } \\
\text { fuscipes }\end{array}$ & $\begin{array}{l}c \\
d\end{array}$ & $\begin{array}{l}29 \\
35\end{array}$ & & $\begin{array}{l}.28 \\
.74\end{array}$ & $\begin{array}{c}(1.13) \\
1.08\end{array}$ & $\begin{array}{l}(.56) \\
.61\end{array}$ & $\begin{array}{c}(2.40) \\
.24\end{array}$ \\
\hline $\begin{array}{l}\text { Calathus } \\
\text { melanocephalus }\end{array}$ & $\begin{array}{l}\text { c } \\
\text { d }\end{array}$ & $\begin{array}{r}4 \\
31\end{array}$ & & $\begin{array}{c}(1.25) \\
.68\end{array}$ & $\begin{array}{r}(1.80) \\
.48\end{array}$ & $\begin{array}{r}(.78) \\
(1.20)\end{array}$ & $\begin{array}{l}(.00) \\
(.08)\end{array}$ \\
\hline $\begin{array}{l}\text { Calathus } \\
\text { piceus }\end{array}$ & $\begin{array}{l}\mathbf{a} \\
\mathbf{b}\end{array}$ & $\begin{array}{l}63 \\
16\end{array}$ & $\begin{array}{c}3.71 \\
(8.00)\end{array}$ & $\begin{array}{l}.87 \\
.75\end{array}$ & & & \\
\hline $\begin{array}{c}\text { Notiophilus } \\
\text { biguttatus }\end{array}$ & $\begin{array}{l}a \\
b \\
c \\
d\end{array}$ & $\begin{array}{r}48 \\
31 \\
114 \\
112\end{array}$ & & $\begin{array}{l}2.46 \\
1.90 \\
3.45 \\
1.06\end{array}$ & $\begin{array}{l}.28 \\
.34\end{array}$ & $\begin{array}{l}.14 \\
.22\end{array}$ & $\begin{array}{l}2.94 \\
4.45\end{array}$ \\
\hline $\begin{array}{l}\text { Notiophilus } \\
\text { rufipes }\end{array}$ & $\begin{array}{l}\text { a } \\
b \\
c \\
d\end{array}$ & $\begin{array}{l}74 \\
78 \\
93 \\
60\end{array}$ & & $\begin{array}{r}2.96 \\
2.32 \\
1.78 \\
.88\end{array}$ & $\begin{array}{l}.30 \\
.42\end{array}$ & $\begin{array}{l}.78 \\
.45\end{array}$ & $\begin{array}{l}1.16 \\
2.20\end{array}$ \\
\hline $\begin{array}{l}\text { Notiophilus } \\
\text { palustris }\end{array}$ & $\begin{array}{l}a \\
b \\
c \\
d\end{array}$ & $\begin{array}{r}2 \\
26 \\
9 \\
6\end{array}$ & & $\begin{array}{c}(2.00) \\
1.46 \\
(3.89) \\
(1.50)\end{array}$ & $\begin{array}{l}.17 \\
\text { (.11) }\end{array}$ & $\begin{array}{r}(.83) \\
(4.00)\end{array}$ & $\begin{array}{l}(1.00) \\
(3.25)\end{array}$ \\
\hline
\end{tabular}




\section{LOCAL DISTRIBUTION}

1. Comparison of the occurrence in oak-mull and oak-mor

As was said in the description, the experimental plots carrying the oak-mull and oak-mor are very close to each other (about $150 \mathrm{~m}$ apart) and the area in between forms a rather regular transition from one to the other. It is not surprising that the two plots have all species in common. However, the densities of most species in these two plots differed in each of the three years of the investigation as may be seen from the total yearly captures.

It is true that groundcover, vegetation and thus microclimate are different but it has been assumed that this difference is of negligible importance with respect to activity and so to captures. For comparison, the total annual capture is regarded as the best available index of density. These are given in

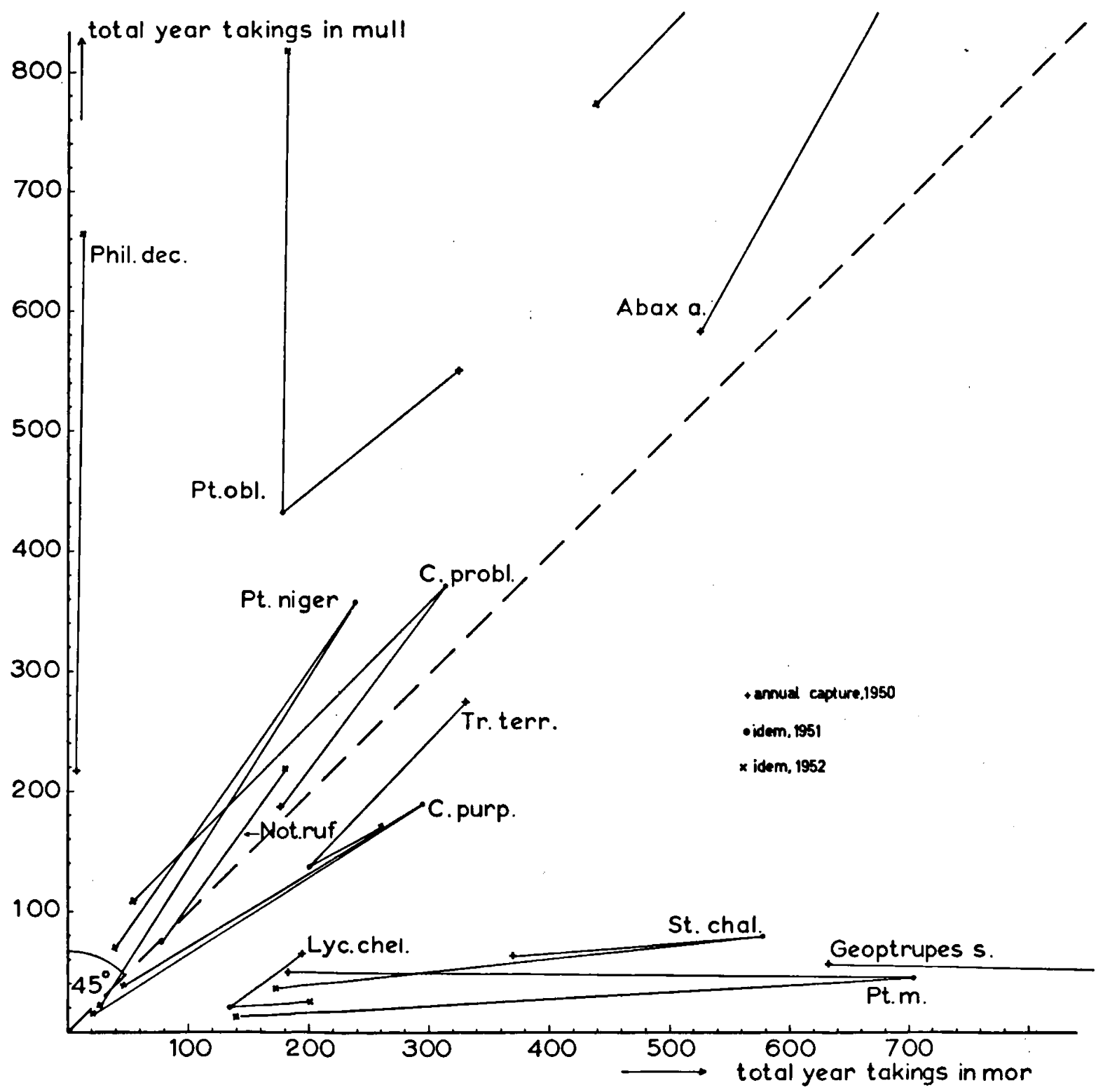

Fig. 7. Comparison of captures of common species in oak mull and oak mor. 
Fig. 7 for each plot in 1950, 1951 and 1952. The the difference in the two stands. This results in the more distant a species is from the $45^{\circ}$-line the greater following comparitive statement:

More numerous in oak-mull

1 Carabus nemoralis

2 Cychrus rostratus

3 Abax ater

$4^{*}$ Pterostichus oblongopunctatus

5 Calathus piceus

6* Notiophilus biguttatus

7 Staphylinus compressus

8 Quedius fuliginosus

9 Philonthus decorus
Both stands about equal

10* Carabus problematicus

$11^{*}$ Carabus violaceus purpurascens

12 Pterostichus niger

$13^{*}$ Notiophilus rufipes

14 Phosphuga atrata

15 Staphylinus brunnipes

$16^{\circ}$ Trochosa terricola
More numerous in oak-mor

17 Pterostichus madidus

$18^{*}$ Notiophilus palustris

$19^{\circ}$ Staphylinus chalcocephalus

20 Quedius lateralis

$21^{\circ}$ Othius punctulatus

$22^{\circ}$ Silpha carinata

$23^{\circ}$ Geotrupes silvaticus

$24^{\circ}$ Lycosa chelata

25 Tarentula trabalis

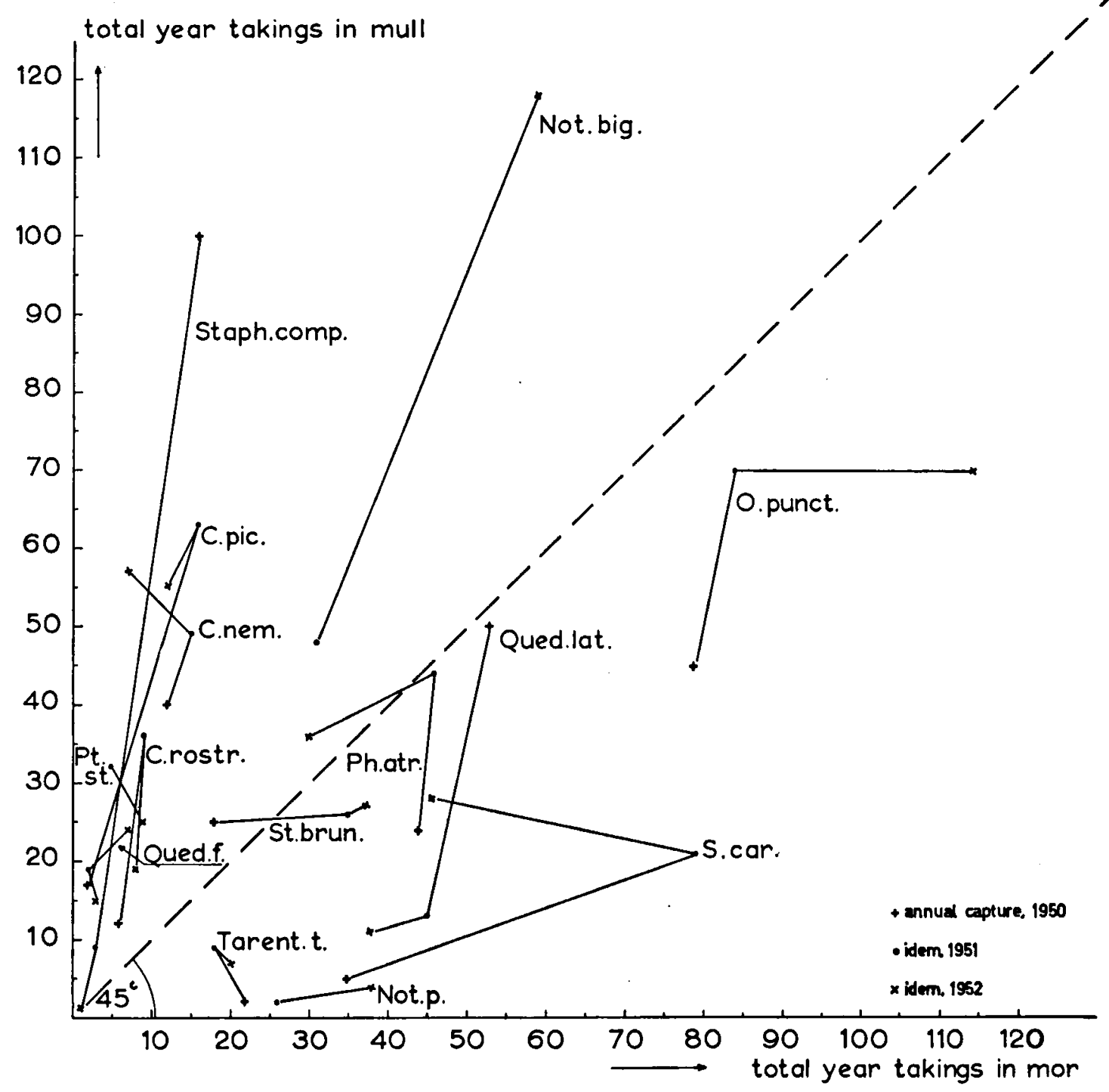


Since there is no difference in the accessibility of the two plots the difference in density must be caused by habitat factors, of which the physical properties of soil and litter layer and the composition of the undergrowth are the most apparent. It seems that the species of the first column are favoured by a loose and crumbly soil with a thin litter layer and those of the third column by a dense vegetation of Vaccinium and a thick raw humus layer.

The species of the second group are apparently unaffected by these factors. It is worth noting that several congeneric species (of Pterostichus, Notiophilus, Staphylinus and Quedius) are distributed over different groups. With respect to the factors involved, Pterostichus niger, Notiophilus rufipes and Staphylinus brunnipes should have a wider ecological amplitude than the two other species of the same genus. Furthermore it may be stressed that the number of species in each of these three groups, which also occur in the pinewood (marked with an asterisk) is greatest in the "mor-preferring" group (6 spp. out of 9) and smallest in the "mull-preferring" one (2 spp. out of 9), the third group being intermediate in this respect (4 spp. out of the total of 7). This suggests that the raw humus layer (present both in the pinewood and in oak-mor) is of importance with respect to habitat preference.

\section{Distribution pattern in the pine wood}

The continuous trapping over a period of 5 years in the pinewood allows a comparison of the distribution pattern of the different species in different years and at various densities. A description of the wood has already been given in the second section. Fig. 8 gives diagrams of the most important vegetation characteristics and additional data. In addition to these factors an important biotic factor, influencing the distribution, is operative. On the places indicated in the diagram ant-hills are present. Ants (Formica rufa polyctena Förster) affect the sampling results, since they were frequently observed attacking the smaller individuals and dragging them out of the traps. Only the neighbouring traps were visited regularly as indicated in the diagram. The small catches from these tins, however, were not only caused by ant activity in the tins. The use of a modified technique in which the animals, entering the trap fell down into tubes of alcohol at the bottom, as well as direct observations in the field suggests that soil intensively scoured by ants is only sparsely occupied by most of the smaller carabid species. In the winter 1954-55 the open part of the forest was cut down. As may be seen in the vegetation diagrams this corresponds to the two southern rows of traps. The soil surface remained actually unaffected until June but it was then ploughed. The ant colonies had moved before this happened: the SW one out of the experimental plot, the $\mathrm{E}$ one about $50 \mathrm{~m}$ in a northerly direction, near the new forest border.

The results of only four species are presented in detail. In Fig. 9 the figures indicate the percentages of the total years' catch given by the different traps. The total catch is given at the base of the diagram.

In Carabus v. purpurascens, the distribution in the

\begin{tabular}{|l|l|l||l|l|}
\hline 1 & 8 & 9 & 16 & 17 \\
\hline 2 & 7 & 10 & 15 & 18 \\
\hline 3 & 6 & 11 & 14 & 19 \\
\hline 4 & 5 & 12 & 13 & 20 \\
\hline
\end{tabular}

A

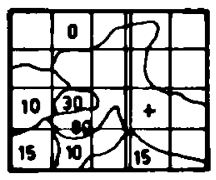

E

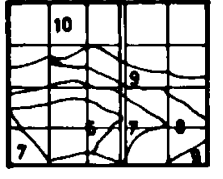

B

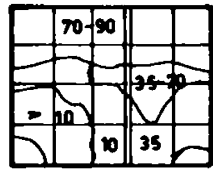

$\boldsymbol{F}$

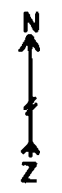

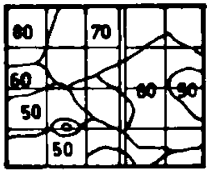

c

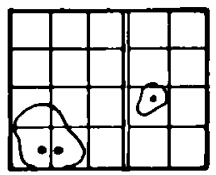

$\mathbf{G}$

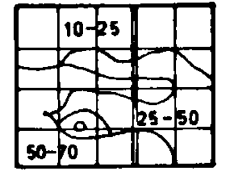

D

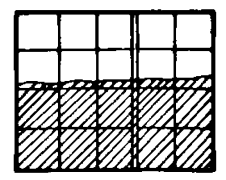

H

Fig. 8. Characteristics of the pine wood area.

A. Arrangement and numbering of the traps in the experimental plot. B. Height of trees in metres. C. Percentages coverage of canopy. D. Percentages coverage of needle litter. E. Percentages coverage of heather $+=$ very scarcely occuring. F. Percentages coverage of Pleurozium Schreberi. G. Ant hills of Formica rufa polyctena and area of activity. H. Area cleared in November 1954 . 
1951 1952

1953

1954

1955

CARABUS VIOLACEUS PURPURASCENS

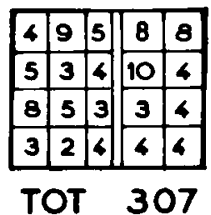

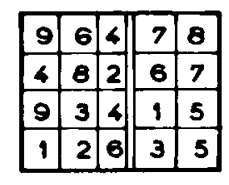

434

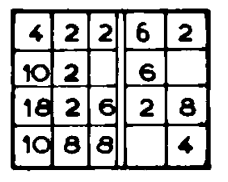

51
IMAGO

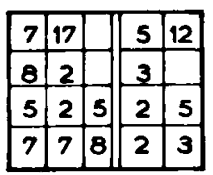

59

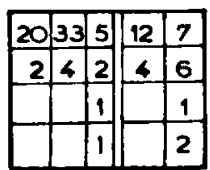

262

CARABUS VIOLACEUS PURPURASCENS

LARVA (NUMBERS)

\begin{tabular}{|l|l|l|l|l|}
\hline 4 & 6 & 4 & 6 & 3 \\
\hline 3 & 2 & & 5 & 4 \\
\hline & 1 & & & 4 \\
\hline 2 & & & 4 & 1 \\
\hline
\end{tabular}

\begin{tabular}{|l|l|l||l|l|}
\hline & 1 & 2 & 5 & 1 \\
\hline 1 & & 1 & & 1 \\
\hline 1 & & & & 1 \\
\hline & & & 3 & 1 \\
\hline
\end{tabular}
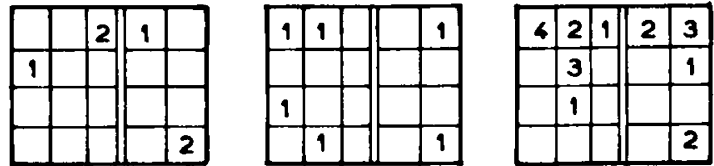

PTEROSTICHUS OBLONGOPUNCTATUS

\begin{tabular}{|c|c|c|c|}
\hline & 1 & & 2 \\
\hline \begin{tabular}{|l|}
11 \\
\end{tabular} & $10 / 3$ & 4 & 2 \\
\hline \begin{tabular}{|l|}
119 \\
\end{tabular} & 213 & 1 & 6 \\
\hline 1 & 28 & & 12 \\
\hline
\end{tabular}

757

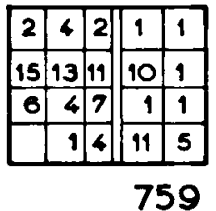

759

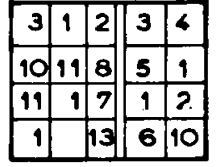

565 .
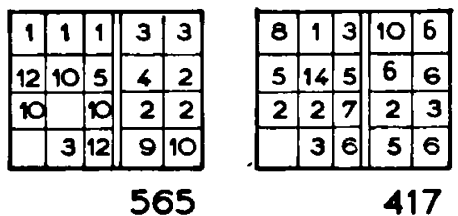

417

CALATHUS MICROPTERUS

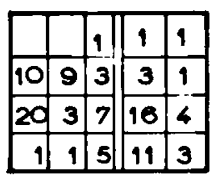

153

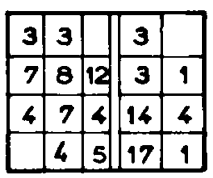

74

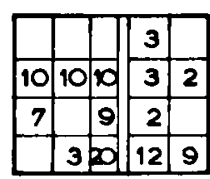

58

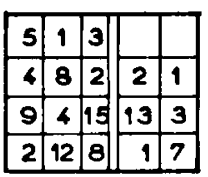

227

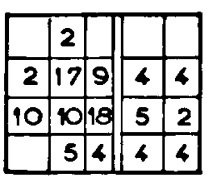

57

\section{GEOTRUPES SILVATICUS}

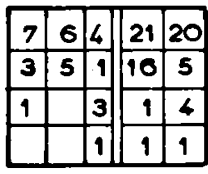

340

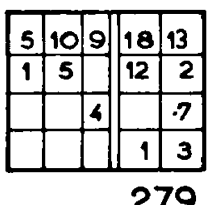

279

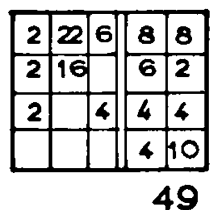

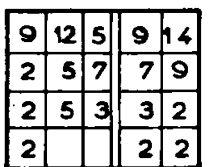

58

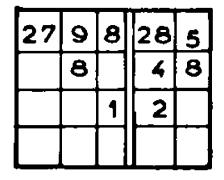

190

Fig. 9. Distribution pattern of four carabid species and one Geotrupes in pine wood in five successive years. Figures give percentages of total year capture in each of the traps indicated at the bottom of each diagram.

years 1951 and 1952 is about the same; there is some preference for the closed part of the forest but the species occurs frequently also in the open part. In the years 1953 and 1954 the captures were very small, influencing the significance of the percentage values. It is remarkable that in traps 4 and 5 relatively large numbers were taken. In 1955 the captures in the felled area were very small, smaller still than in the corresponding traps of the preceding years. From the remaining part of the forest, however, captures were significantly higher than in the preceding year, exceeding by far the loss in the felled part, suggesting a remarkable increase in population density. Surprisingly large are the catches in traps 1 and 2 throughout the period of activity. The larvae, though taken in much smaller numbers (numbers 
taken in winter 1951/52 indicated in diagram under 1951 etc.) show a distribution that corresponds rather well with the distribution of the imagines. It may be concluded that the distribution pattern remained constant in the first two years. Then, after a significant reduction in numbers, the density again increased (in the unchanged part of the forest), resulting in a pattern quite different from the pattern of the first two years.

Pterostichus oblongopunctatus shows a distribution quite different from the distribution of the previous species. Numbers change only slightly and the distribution pattern remains virtually the same throughout the four years. It seems evident that this species is scarce at the highest parts with a dense Pleurozium cover. On the other hand, it avoids areas traversed intensively by Formica rufa as is indicated by the very small capture from traps 4,5 and 14 , which are all situated where ant activity is very great. Probably the small catches in trap 6 were due to the extremely dry and sunny situation of this trap: the northern margin of a small heather patch. Evidently this species prefers the light and open forest vegetation. After clear-cutting the number taken decreased to some extent, but even after ploughing a few were still taken. In traps 1 and 16 a remarkable increase in capture suggesting a re-distribution, the cause of which in unknown.

The distribution of Calathus micropterus also shows very little change over the years 1951 to 1954 . It is somewhat different in 1953 probably due to the small catches, but the general type of distribution remains unaffected. The average distribution over the years 1951-1954 agrees rather well with the distribution of the preceding species. However, it seems to be less affected by ant activity, since captures in traps 5 and 14 are rather high. Clear cutting seems to have affected the distribution only slightly, though the numbers are markedly reduced. Even after ploughing this species is caught regularly on the bare sand plain.

Geoptrupes silvaticus is greatly concentrated in the highest part of the forest with a dominant Pleurozium vegetation on the floor and thus seems to have a preference quite different from the preference shown by Pterostichus oblongopunctatus. As in Carabus $v$. purpurascens captures in traps 9 and 10 are constantly lower than in the adjacent traps. It is remarkable that the distribution pattern of this species is so distinct, since it is known to run rather quickly and frequently. It suggests that the preference for the higher part is very pronounced, but the operative factors are unknown.
It may be seen that in the last three species the distribution pattern in the successive years is rather stable. There is no indication of a distinct change in distribution with changing density.

It must be admitted that the method is rather coarse and it is possible that more refined sampling methods would indicate such differences in distribution at different densities. It seems probable, however, that these differences are only slight.

The remaining species again do not give indications of distinct changes over the years. The diagrams given in Fig. 10 present the distribution pattern, based on the total catches of 1951-1954. The total number caught is indicated at the bottom.

They apparently fall into four groups: species without any distinct difference in preference for one or other of these varied areas: Carabus problematicus; species with a more or less pronounced preference for the higher and closed part of the forest with its accompanying properties: Carabus v. purpurascens, Notiophilus biguttatus and N. rufipes, Geotrupes silvaticus, Staphylinus chalcocephalus, Othius punctulatus, Silpha carinata and Trochosa terricola; species with a preference for the lower and open part of the forest with its characteristics: Pterostichus oblongopunctatus, P. angustatus, Calathus micropterus, Lycosa chelata; species showing a marked peak in the part of the low forest with heather undergrowth: Calathus erratus, C. melanocephalus and C. fuscipes. It is remarkable here that the congeneric species show about the same distribution pattern: Pterostichus, Calathus and Notiophilus.

Clearing followed by ploughing has had a great influence on the distribution of the species. Before ploughing the effect of the clearing was slight only in Pterostichus oblongopunctatus and Trochosa terricola and apparently in the latter species a small population maintained itself after ploughing. Of $P$ oblongopunctatus only a few individuals were trapped after ploughing in this plot from which this species has probably now been eradicated.

Other species that disappeared almost wholly are Carabus v. purpurascens, Calathus fuscipes, and Silpha carinata whereas Carabus problematicus decreased considerably. On the other hand some species increased on the cleared plot even after ploughing: Pterostichus angustatus, Notiophilus biguttatus and $N$. rufipes. In the first species it is most probably a direct influence of the clearing. Compared with the average captures of this species in the preceding four years, which differed only slightly from each other, the most northern row of traps yielded about the same number, the second row in the new forest 


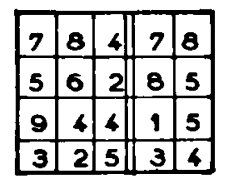

1. Carabus violaceus purpurascens (800).

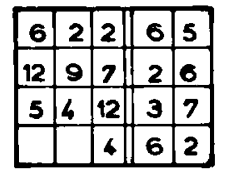

5. Pterostichus angustatus (277).

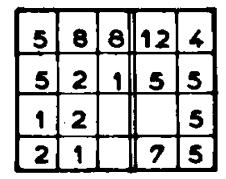

2. idem larvae (72).

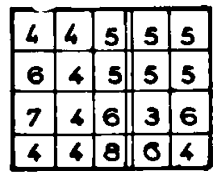

3. Carabus problematicus (559).

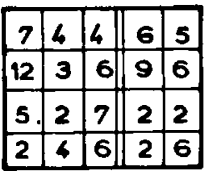

4. idem larvae (195).

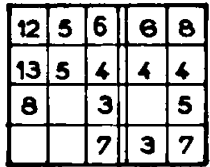

9. Notiophilus rufipes (477).

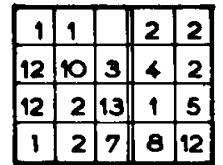

6. Pterostichus oblongopunctatus (2605).

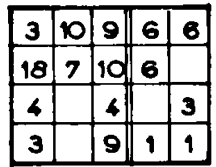

7. Notiophilus palustris (75).

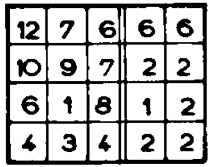

8. Notiophilus biguttatus (905).

\begin{tabular}{|l|l|l|l|l|}
\hline 7 & 3 & 3 & 3 & 1 \\
\hline 4 & 4 & 5 & 3 & \\
\hline 9 & 9 & 8 & 1 & 2 \\
\hline & 1 & 23 & 13 & 1 \\
\hline
\end{tabular}

13. Calathus fuscipes (156).

\begin{tabular}{|c|c|c||c|c|}
\hline 12 & 5 & 7 & 1 & 2 \\
\hline 4 & 2 & 8 & 6 & 1 \\
\hline 5 & 6 & 4 & 12 & 3 \\
\hline 2 & 2 & 6 & 10 & 12 \\
\hline
\end{tabular}

17. Byrrhus sp. (132).

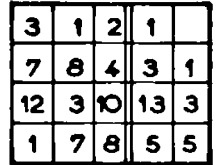

10. Calathus micropterus (469).

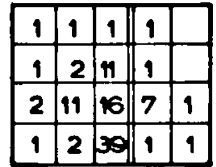

11. Calathus erratus (142).

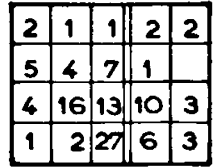

12. Calathus melanocephalus (49).

Fig. 10. Distribution pattern of surface arthropods in pine wood, based on captures from 1951 until 1954 inclusive. Numbers give percentage of total capture, indicated behind the name of the species.

border yielded twice as many and the two rows in the clearing as much as four times as many. Evidently this species prefers the cleared surface, the numbers diminished, however, after ploughing. The first fact agrees with the observations mentioned by LINDROTH (1945) that $P$. angustatus suddenly increases on burnt areas in the forest.
Several species, up till now never found in the pinewood, occurred suddenly on the sand plain. Among them must be mentioned Broscus cephalotes (21 ind.), occurring immediately after felling and present throughout the following year. Apparently this species was attracted by the new conditions. 


\section{E. PHENOLOGY}

Though the series of years is short it is of interest to trace the validity of the data with respect to phenological phenomena. Phenology may be described as "the study of the sequence of natural events throughout the year, and the changes in date from year to year and from place to place" (Williams, 1949). The quantitative description of the occurrence of surface fauna-species as was given in chapter 3 may thus also be reckoned as phenological. Here only the second part of the definition matters: the changes in date from year to year and from place to place.

There are several drawbacks in the available material with respect to phenology. The first concerns the rather conspicuous changes in total capture from year to year and from place to place, due to different densities. In a year or on a place with higher density first capture may be expected at an earlier date. Thus it must be kept in mind that late occurrence of a species in the catches may be caused by its low density. This difficulty can be avoided to some extent by neglecting incidental early or late catches in years with high density. A second difficulty is the interval of a week between two collecting dates by which it is impossible to correlate the catch exactly with meteorological conditions. Since no meteorological data are available for the region concerned, the weeks of the first and the last uninterrupted occurrence are compared with the decade-averages of the maximum and minimum temperatures of the Royal Meteorological Institute of De Bilt about 50 $\mathrm{km}$ west. Comparison of these data with those of Winterswijk (about $60 \mathrm{~km}$ east) shows a rather good agreement and thus it may be taken for granted that the application of these data as characteristics of the macroclimate is valid.

Only species caught in all the years and in sufficient numbers were handled in this way viz. the carabids Pterostichus oblongopunctatus, Carabus $v$. purpurascens, C. problematicus and the spider Trochosa terricola. In Fig. 11 a graph is given of the average decade maximum and minimum temperatures of the years 1950-1955.

The periods of activity of Pterostichus oblongopunctatus, Carabus problematicus, C. purpurascens and Trochosa terricola are indicated. It seems that the period of occurrence of Pterostichus oblongopunctatus is rather well correlated with surpassing the $10^{\circ} \mathrm{C}$ level of the average decade maximum temperature.

In Carabus v. purpurascens activity is correlated with surpassing the average decade minimum temperature of $9^{\circ} \mathrm{C}$. In Carabus problematicus and Trochosa terricola the beginning and ending of activity are at different levels: in $C$. problematicus these are average decade minima of $8^{\circ}$ and $6^{\circ} \mathrm{C}$ respectively and in Trochosa terricola $1^{\circ}$ and $6^{\circ} \mathrm{C}$ respectively. That the correlation is better with maximum temperatures in Pterostichus and with minimum temperatures in the other species may be caused by the fact that the first species has mainly diurnal activity, the others nocturnal activity. It is evident that the correlations stated do not have the character of a causal relationship. Nevertheless they indicate that temperature may be an important factor in activating the species concerned. This is sustained by the fact that extreme high and extreme low temperatures increase and decrease the catches.

Since animals react to microclimatological conditions, it is clear that there must be phenological differences in so markedly diverging stands as the pinewood and the oakwoods. For comparison it is necessary that in both woods the species are caught in rather large numbers. This is the case with Pterostichus oblongopunctatus in both years that captures were made simultaneously in the pine- and the oakwood. The first catches were a week earlier in the pinewood and a peak was reached sooner. A great difference was noted in the first occurrence of the freshly emerged adults in this species. In the pinewood this date was three weeks earlier in both years.

The first fact points to earlier activation of the animals in spring, the second one to quicker development of larvae in summer, both probably caused by higher temperatures in the litter layer of the pinewood. This earlier first occurrence in the pinewood by 1-2 weeks, was noted also for Carabus problematicus and C. v. purpurascens. 


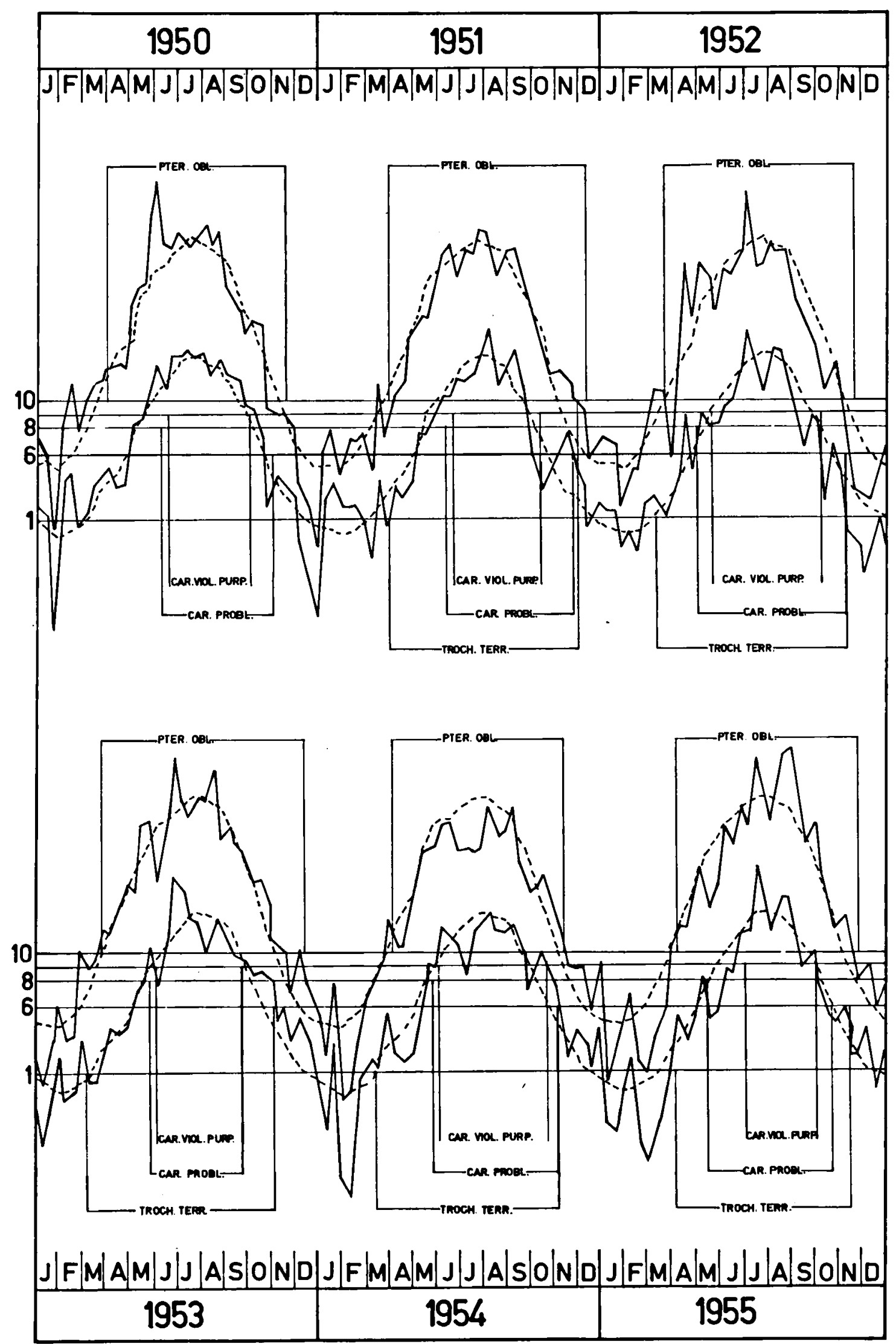

Fig. 11. Period of regular occurrence of Pterostichus oblongopunctatus, Carabus v. purpurascens, Carabus problematicus and Trichosa terricola in relation to average decade maximum and average decade minimum temperatures respectively. The fifty years average of these temperatures is given by the broken line. 


\section{CONCLUSION AND SUMMARY}

Baitless trapping of the macroarthropod surface fauna in an oak- and a Scots pinewood for several successive years has revealed that each species has its characteristic period of occurrence, often showing a marked difference from that of related species (Fig. 3, 4 and 5). The periods of occurrence differ only slightly from year to year and from place to place (Fig. 1), they coincide with differences in temperature (Fig. 11) and they are probably mainly caused by these differences. Within the period of occurrence distinct periodic differences in the catches can be recognised, mainly caused by periodic differences in activity. The histogram of the weekly captures in percentages of the total year capture is called activogram. The activogram characterises the species with respect to its developmental type: species with summer larvae, with reproduction and highest captures in spring and/or early summer, and species with winter larvae, with these items in summer and/or autumn. The shape of the curves characterises the species with respect to the dispersion in the time at which activity first begins and the individual duration of activity: small dispersion and short individual activity giving rise to a steep-sided and short curve and the reverse to a slow-sided and long curve (Fig. 2). Comparison of the data presented here with those from literature (Table 1) shows that in the category of "species with winter larvae", the reproductive period occurs progressively earlier with increasing latitude. In two species, Carabus problematicus and Calathus micropterus, this results in a complete change-over in the type of life cycle from one with winter larvae in the south to the type with summer larvae much further north. It is suggested that this is an adjustment to the adverse winter conditions in northern latitudes. In the category of "species with summer larvae", a retardation of the reproductive period occurs, probably caused by the later spring.

In the type of life cycle involving winter larvae, three different types of active imagines can be discerned, viz.: beetles, that hibernated as imagines, reproduced in the preceding year and which are expected to reproduce for a second time; newly emerged adults, which, after a short period of intense activity, have a period in which activity is reduced to a differ- ent degree in the different species; mature imagines, the re-activated old and young animals which reproduce.

The long and intense resting period in Carabus problematicus causes two peaks in the histogram representing immature and mature activity (Fig. 3, 6). In the other species the resting period is shorter and inactivation less intense and therefore the two activity periods merge into each other (Fig. 3).

In general the fluctuations in density of species in the different plots agree with each other rather well (Table 3). It is suggested that the fluctuations are mainly caused by meteorological conditions. In the population changes which occurred during these five years, there is a greater resemblance between species which have the same type of life cycle (i.e. either winter larvae or summer larvae) than between species of different type. This also points to the fact that the influence of meteorological conditions is considerable. The influence of continued bait-less trapping upon local population density could not be accurately assessed but this is believed to be negligible. The ratios of the annual captures in any two successive years for all species do not show a tendency of decrease (Table 2).

The distribution pattern changes little during the successive years, notwithstanding fluctuations in density, (Fig. 9). It is clear that the preferences of several species for certain conditions are very pronounced, even within areas which superficially appear homogeneous. The analysis of the causative factors will be a subject for further research.

\section{Acknowledgements}

It is a pleasant duty for the author to thank the owners of the forests in which was collected during so long a time: the Board and the director of the National Park "De Hoge Veluwe", ir. J. H. van TuYL, and Douarière S. A. M. Repelaer van SpIJKenisse, owner of "Deelerwoud". I am also indebted to Dr. P. F. Baron van Heerdt (Utrecht) for his assistance in collecting part of the material and to Dr. Edward Broadhead (Leeds) for correction of the english text. 


\section{LITERATURE}

Delkeskamp, K., 1930: Biologische Studien über Carabus nemoralis Müll. Z. Morph. ökol. Tiere 19, (1), 1.

Emden, F. van, 1933: Uber die erbliche Bindung von Latenzen an Jahreszeiten. V Congres Intern. d'Entom. II Travaux.

Escherich, K., 1923: Die Forstinsekten Mitteleuropas II. Parey, Berlin.

Forbes, S. A., 1882: The food relations of the Carabidae and Coccinellidae. Bull. Ill. State Lab. of Nat. Hist. 1, (6), 33-60.

Gilbert, O., 1956: The Natural Histories of four species of Calathus, living on sand dunes in Anglesey, North Wales. Oikos 7, 1, 22-47.

Graham, S. A., 1939: Principles of forest Entomology. McGraw Hill, New York.

Henseler, C., 1940, 41: Carabus violaceus L. und purpurascens F. in Deutschland. Entom. Bl. 36, (5), 152157 , and id. $37,(3), 117-118$.

Jung, W., 1940: Ernährungsversuche an Carabus Arten. Entom. Bl. 36.
Kern, P., 1912: Uber die Fortpflanzung und Eibablage bei einigen Caraben. Zool. Anz. 40, 345-351.

Kern, P., 1921: Beitrage zur Biologie der Caraben. Entom. Bl. 17.

Kirchener, H., 1927: Biologische Studien uiber Carabus cancellatus. Z. Morph. Ökol. Tiere, 7, 489-534.

Larsson, S. W., 1939: Entwicklungstypen und Entwicklungszeiten der dänischen Carabiden. Entom. Medd. 20, 277-554.

LENGERKEN, H. v., 1921: Carabus auratus und seine Larve. Arch. Naturgesch. Abt. A. 87.

Lindroth, C. H., 1949: Die Fennoskandischen Carabiden Medd. Göteborgs Mus. Zool. Avdeln. 122.

Oertel, R., 1924: Biologische Studien über Carabus granulatus Zool. Jb. Syst. 48, 299.

VITÉ, J. P., 1953: Untersuchungen über die ökologische und forstliche Bedeutung der Spinnen im Walde. $Z$. Angew. Entom. 34, (3), 313-334.

Williams, C. B., 1949: The Biology of the seasons. New Naturalist 5. 